\title{
„Osoba podejrzana”, „podejrzany” i „oskarżony” w polskim procesie karnym - zakres pojęciowy ${ }^{1}$
}

\begin{abstract}
The subject of this article is nomenclatural interpretation of the notions of "a person of interest", "a suspect" and "a defendant" in Polish Code of Criminal Procedure - the parties in criminal proceedings who are suspected of committing a crime or who are charged with a crime. The article discusses the legal definitions of the word "suspect" according to Article $71 \S 1$ of the Code of Criminal Procedure (i.e. a person against whom a statement of objections has been issued and a person who has been charged on the grounds of examination of the person in question as a suspect) as well as the word "defendant" according to Article $71 \S 2$ and 3 of the Code of Criminal Procedure (sensu stricto and sensu largo). Moreover, the article provides an overview of the available definitions of "a suspect" and "a person of interest" - parties named directly in the Code of Criminal Procedure.

In addition to that, the article discusses the notion of "actual suspect" (whose definition and understanding varies in the doctrine), which emerged from the previously effective Code of Criminal Procedure. The article analyses the legal standing of such an "actual suspect" in the context of Article $233 \S 1 \mathrm{a}$ of the Criminal Code (a regulation which is considered potentially unconstitutional).

While discussing the figure of the "suspect", the author analyzes terms such as "issuing" and "preparation" - in connection with Article $71 \S 1$ and $313 \S 1$ of the Criminal Code and the lack of agreement within the discipline regarding the precise time at which the statement of objections has been issued (which is connected with obtaining the position of the passive party to proceedings in criminal procedure).

Moreover, the article discusses in some detail the legal standing of a person against which a motion has been presented, according to Article 354 of the Code of Criminal Procedure, regarding the discontinuation of proceedings and issuing preventive measures protecting the person of an insane perpetrator - in the context of nomenclature.
\end{abstract}

Key words: defendant, suspect, person of interest

${ }^{1}$ Artykuł jest rozszerzonym i zaktualizowanym fragmentem pracy doktorskiej pt. Wyjaśnienia oskarżonego jako dowód w polskim procesie karnym, napisanej w Katedrze Prawa Karnego Procesowego Wydziału Prawa i Administracji Uniwersytetu Śląskiego w Katowicach. 
1.

W polskim procesie karnym oskarżony jest bierną stroną procesową przeciwko niemu toczy się postępowanie karne. W związku z tym bardzo ważną rolę odgrywają same definicje legalne określające tego uczestnika procesu karnego, ponieważ za ich pomocą można ustalić początek bytu prawnego tej strony procesowej. I chociaż pojęcie „oskarżonego” zostało zdefiniowane w art. $71 \S 2$ k.p.k., podobnie zresztą jak ,podejrzanego” (art. $71 \S 1$ k.p.k.), to jednak określenie początku uzyskiwania statusu biernej strony procesowej nie jest tak oczywiste, jak to wynika z definicji legalnych, dlatego też celowe jest szersze omówienie tych pojęć. Poza tym należy zauważyć, że ze wskazanymi pojęciami nierozerwalnie wiąże się problematyka „osoby podejrzanej” oraz „osoby podejrzewanej o popełnienie przestępstwa” („osoby potencjalnie podejrzanej”). Przy czym ustawodawca nie zdecydował się na wprowadzenie definicji legalnych tych uczestników, choć pierwszy z nich (osoba podejrzana) jest wymieniony wprost w Kodeksie postępowania karnego i wobec niego można wykonywać pewne czynności procesowe. Dlatego też niezbędne stało się także omówienie tych dwóch pojęć, jako że wykonywane wobec takich osób czynności procesowe bardzo często ingerują w prawa i wolności człowieka.

\section{2.}

Pojęcie „osoby podejrzewanej o popełnienie przestępstwa” nie może być utożsamiane $\mathrm{z}$,osobą podejrzaną”. A to dlatego, że o osobach podejrzewanych nie ma w ogóle mowy w żadnym z przepisów Kodeksu postępowania karnego, jednakże trafnie wskazuje się, iż trzeba odróżnić osoby podejrzewane, wśród których dopiero poszukuje się domniemanego sprawcy konkretnego przestępstwa, od osoby podejrzanej². Tym samym osoba podejrzewana to ta, która pozostaje w obrębie zainteresowania organów ścigania, w stosunku do której prowadzi się czynności operacyjne, a więc pozostająca „w kręgu podejrzeń” organów ścigania (wobec której

2 A. Murzynowski: Faktycznie podejrzany w postępowaniu przygotowawczym. Pal. 1971, nr 10, s. 37; T. HANAUSEK: Niektóre aspekty pracy z podejrzanym $w$ świetle kryminalistyki i procesu karnego. ZNASW 1976, nr 16, s. 36; K. OтŁоWsкI: Kryminalistyczne ujęcie potożenia prawnego podejrzanych $w$ postępowaniu przygotowawczym. Warszawa 1982, s. 12; I. DzIUGIEt: Sytuacja prawna osoby podejrzanej na tle przepisów kodeksu postępowania karnego z 1997 roku. Wybrane zagadnienia. W: Ochrona człowieka w świetle prawa Rzeczypospolitej Polskiej. Materiaty z II Międzynarodowej Konferencji Naukowej. Miarki 18-19 października 2001 r. Red. S. Pikulski. Olsztyn 2002, s. 328; Z. Sobolewski. P.K. Sowiński. W: G. ArtyMiaK et al.: Proces karny. Część ogólna. Red. G. Artymiak, M. Rogalski, Z. SobolewsKi. WarszawaKraków 2007, s. 120. 
podejmuje się czynności sprawdzająco-eliminacyjne $\left.{ }^{3}\right)$. Osobę taką nazywa się też „potencjalnie podejrzaną” - co do której zakłada się, iż może być sprawcą przestępstwa ${ }^{4}$. Tak więc jest to ktoś, kto znalazł się w grupie osób wytypowanych jako możliwi sprawcy czynu zabronionego ${ }^{5}$, czyli ten mogący mieć związek z danym przestępstwem (a który to związek ustala się na podstawie wiedzy dotyczącej zdarzenia) $)^{6}$. A zatem osoba podejrzewana o popełnienie przestępstwa znajduje się wśród takiej grupy ludzi, którzy uważani są przez organy ścigania za możliwych i potencjalnych sprawców konkretnego czynu zabronionego. Poza tym wobec takiej osoby podejmuje się operacyjne czynności sprawdzające w celu potwierdzenia lub wykluczenia związku z danym przestępstwem.

Należy wskazać, iż posługiwanie się pojęciem „osoby podejrzewanej” $\mathrm{w}$ procesie karnym jest zasadne. Trzeba bowiem zwrócić uwagę, iż z art. 192a § 1 i 2 k.p.k. pośrednio można wnioskować o istnieniu takich osób, gdyż zgodnie z tymi przepisami spośród pewnej grupy ludzi, poprzez np. pobieranie materiału genetycznego, ogranicza się krąg osób podejrzanych. Wobec tego wykonywane w stosunku do nich czynności operacyjne, procesowe mogą dopiero pozwolić na ustalenie konkretnej osoby podejrzanej o popełnienie przestępstwa.

3.

W doktrynie prawa karnego procesowego pojawiło się również pojęcie „faktycznie podejrzanego”. Stworzono je na tle regulacji art. $61 \S 1$ k.p.k. z 1969 r., ponieważ wtedy podejrzanym była tylko osoba, co do której wydano postanowienie o przedstawieniu zarzutów ${ }^{7}$. Z kolei inne

${ }^{3}$ E. KuRleto: Osoba „podejrzewana” o dokonanie przestępstwa. PP 1981, nr 6, s. 22.

${ }^{4}$ Z. SoвolewsKi: Osoba podejrzana oraz potencjalnie podejrzana $w$ znowelizowanym (2003) kodeksie postępowania karnego a gwarancje konstytucyjne. W: Problemy znowelizowanej procedury karnej. Materiały z konferencji naukowej Rzeszów-Czarna 17-18 października 2003 r. Red. Z. Sobolewski, G. ArtymiaK, C.P. KŁaK. Kraków 2004, s. 331.

5 A. CZAPIGo: Osoba podejrzana jako podmiot uprawniony do wniesienia zażalenia na postanowienie o umorzeniu postępowania przygotowawczego. „Wojskowy Przegląd Prawniczy” 2009, nr 2, s. 45; S. STEINBORN: Status osoby podejrzanej w procesie karnym z perspektywy Konstytucji RP (Uwagi de lege lata i de lege ferenda). W: Państwo prawa i prawo karne. Księa jubileuszowa Profesora Andrzeja Zolla. T. II. Red. P. Kardas, T. SROKA, W. WróBEL. Warszawa 2012, s. 1781.

${ }^{6}$ C.P. KŁAK: „Osoba podejrzana” oraz „potencjalnie podejrzana” $w$ polskim procesie karnym a zasada nemo se ipsum accusare tenetur. IN 2012, nr 4, s. 59-60.

7 F. Prusak: Faktycznie podejrzany $w$ procesie karnym. Pal. 1971, nr 3, s. 33; A. Murzynowski: Faktycznie podejrzany..., s. 37; E. Karski: Podejrzany a osoba podejrzana i ich charakter wedtug kodeksu postępowania karnego. NP 1976, nr 5, s. 754. 
przepisy ówczesnego Kodeksu postępowania karnego pozwalały w niektórych przypadkach na przesłuchanie osoby podejrzanej w charakterze podejrzanego (np. art. 210 \$2, $276 \S 1$ k.p.k. z 1969 r.), bez przyznania jej wprost pozycji procesowej podejrzanego. „Faktycznie podejrzanym” określano osobę, przeciwko której prowadzone były czynności śledcze, ale co do której nie wydano formalnego postanowienia o przedstawieniu zarzutów ${ }^{8}$.

$\mathrm{W}$ aktualnym stanie prawnym $\mathrm{w}$ doktrynie, $\mathrm{z}$ uwagi na brzmienie art. $71 \S 1$ k.p.k. (w którym zawarta jest definicja podejrzanego), najczęściej „faktycznie podejrzanym” nazywa się osobę, przeciwko której organy procesowe kierują ściganie karne poprzez czynności procesowe, lecz nie stawiają jej w pozycji podejrzanego, chociaż istnieją podstawy, by wydać w stosunku do niej postanowienie o przedstawieniu zarzutów ${ }^{9}$. Tym samym „faktycznie podejrzanym” jest ktoś, komu nie przedstawiono zarzutów, mimo że istnieją podstawy do dokonania wobec niego takiej czynności procesowej. Oznacza to, że dana osoba zamiast zostać podejrzanym, jest np. celowo przesłuchiwana w charakterze świadka. Najczęściej będzie to oczywiście faktyczny sprawca przestępstwa, lecz nie zawsze tak jest. I chociaż sytuacje takie nie powinny mieć w ogóle miejsca, w razie ich zaistnienia osobę taką można nazywać właśnie „faktycznie podejrzaną”. Z kolei nie można określić jej mianem „faktycznego sprawcy przestępstwa", gdyż ustalenie sprawstwa i winy następuje dopiero w trakcie postępowania karnego. Poza tym zdarzają się sytuacje, że w postępowaniu przygotowawczym stawia się zarzuty osobom niewinnym. Reasumując, wyodrębniając „faktycznie podejrzanego”, można lepiej chronić osobę pozycją procesową osoby, która winna uzyskać status procesowy podejrzanego. W związku z tym nie można zgodzić się z poglądem, że pojęcie „faktycznie podejrzanego” jest tożsame z „osobą podejrzaną"10, ponie-

${ }^{8}$ Szerzej zob.: F. Prusak: Faktycznie podejrzany..., s. 32-47; M. BŁoński: Wyjaśnienia oskarżonego w polskim procesie karnym. Łódź 2011, s. 23-30.

9 A. TARACHA: Glosa do postanowienia SN z 2 lipca 2003 r., II KK 268/02. „Wojskowy Przegląd Prawniczy" 2006, nr 1, s. 156-157; E. Skrętowicz. W: R. KMiEciK, E. SKrętowicz: Proces karny. Część ogólna. Warszawa 2009, s. 163; G. Krzysztofiuk: Prawo do obrony osoby podejrzanej oraz faktycznie podejrzanego - uwagi na tle uchwat Sadu Najwyższego z 26.4.2007 r. (I KZP 4/07) oraz z 20.9.2007 r. (I KZP 26/07). W: Problemy prawa polskiego i obcego $w$ ujęciu historycznym, praktycznym i teoretycznym. Cześć druga. Red. B.T. Bieńkowska, D. Szafrański. Warszawa 2009, s. 165; R. KMIECIK: Akt oskarżenia jako pisemna forma skargi oskarżyciela publicznego. Prok. i Pr. 2010, nr 1-2, s. 118; Z. Brodzisz. W: Z. BrodzISZ et al.: Kodeks postępowania karnego. Komentarz. Red. J. SKoruPKA. Warszawa 2015, s. 756; G. JĘDRZEJEWsKI: Odpowiedzialność karna świadka za niektóre przestępstwa przeciwko wymiarowi sprawiedliwości. Prok. i Pr. 2017, nr 2, s. 59.

10 S. Waltoś: Proces karny. Zarys systemu. Warszawa 2008, s. 195; M. BŁoński: Wyjaśnienia oskarżonego..., s. 30-31; K. WiткоWsKa: Strony procesowe i ich reprezen- 
waż jego zaaprobowanie spowodowałoby zatarcie różnic między „osobą podejrzaną" w ujęciu kodeksowym a tą osobą, której nie przedstawia się zarzutów w sytuacji zaistnienia uzasadnionego podejrzenia popełnienia przestępstwa. Warto także dodać, że rozstrzygnięcie tego, czy dana osoba była rzeczywiście „faktycznie podejrzaną”, możliwe będzie dopiero w dalszym etapie postępowania karnego.

\section{4.}

W Kodeksie postępowania karnego nie istnieje legalna definicja „osoby podejrzanej”, choć pojęcie to używane jest w wielu różnych przepisach (np. art. 219 § 1, 244 § 1 k.p.k.). Niemniej jednak najczęściej określa się osobę podejrzaną ${ }^{11}$ jako tą, wobec której koncentrują się określone działania przewidziane przez przepisy prawa karnego procesowego ${ }^{12}$. Tym samym osoba podejrzana to ta, którą podejrzewa się o popełnienie przestępstwa (przypuszczając, iż je popełniła), lecz której nie przedstawiono zarzutu jego popełnienia $^{13}$, a organy ścigania, posiadając o niej informacje, koncentrują wokół niej różnego rodzaju działania ${ }^{14}$. Trafnie w związku

tanci $w$ postępowaniu przygotowawczym. Prok. i Pr. 2012, nr 9, s. 112; K.T. BoratyŃsKa. W: K.T. Boratyńska, Ł. Chojniak, W. Jasiński: Postępowanie karne. Warszawa 2015, s. 166.

11 Zob. także szczegółowy przegląd definicji „osoby podejrzanej” - R.A. STEFański: Prawo do obrony osoby podejrzanej. W: Z problematyki funkcji procesu karnego. Red. T. GrzegorczyK, J. IzydorczyK, R. Olszewski. Warszawa 2013, s. 296-300.

12 S. OwCZARSKI: Osoba podejrzana i podejrzany $w$ dochodzeniu nie cierpiacym zwłoki $w$ świetle badań. „Wojskowy Przegląd Prawniczy” 1994, nr 1, s. 20; F. PrusaK: Komentarz do kodeksu postępowania karnego. Warszawa 1999, s. 276; P. HofmańsKi, E. SAdzIK, K. ZgryzeK: Kodeks postępowania karnego. T. I: Komentarz do artykułów 1-296. Warszawa 2011, s. 483.

${ }_{13}$ W. DAszKIEWICZ: Prawo karne procesowe. Zagadnienia ogólne. T. I. Poznań-Bydgoszcz 1999, s. 249; A. CZAPIGO: Oskarżony jako źródło dowodowe. „Prokurator” 2001, nr 1, s. 67; M. KlejnowsKa: Osoba podejrzana $w$ procesie karnym. „Prokurator” 2003, nr 2, s. 38; K. Marszat. W: K. Marszae, S. Stachowiak, K. ZgryzeK: Proces karny. Katowice 2003, s. 189-190; Z. Sobolewski: Osoba podejrzana..., s. 330; T. GrZEgorczyк. W: T. GrzegorCZYK, J. Tylman: Polskie postępowanie karne. Warszawa 2009, s. 310-311; Z. MuRas: Wyjaśnienia oskarżonego w procesie karnym i prawie karnym materialnym. Komentarz. Warszawa 2010, s. 47; M. BŁońsкI: Wyjaśnienia oskarżonego..., s. 31; W. Grzeszczyк: Kodeks postępowania karnego. Komentarz. Aktualizacja A. Herzog. Warszawa 2014, s. 121; S. SteInBorn, J. Grajewski. W: J. Grajewski, L.K. Paprzycki, S. Steinborn: Komentarz aktualizowany do art. 1-424 ustawy z dnia 6 czerwca 1997 r. Kodeks postępowania karnego, LEX/el. 2015, teza 3 do art. 71 k.p.k.

14 Z. Gostyński, S. ZabŁocki. W: J. BratoszewsKi et al.: Kodeks postępowania karnego. Komentarz. T. I. Warszawa 2003, s. 513; podobnie: A. BAJ: Czy osoba podejrzana jest strona postępowania przygotowawczego?. Prok. i Pr. 2016, nr 10, s. 87; M.R. JAsIŃsKa: Źródta informacji o popetnionym przestępstwie. Szczecin 2016, s. 169; E. KowalewsKa-Borys. 
z tym wskazuje się, iż wobec osoby podejrzanej istnieje jedynie przypuszczenie, że popełniła przestępstwo, a brak jest dostatecznie uzasadnionego podejrzenia jego popełnienia ${ }^{15}$ (a które to pojęcie jest zdecydowanie węż$\left.\mathrm{sze}^{16}\right)$. A zatem muszą zaistnieć takie dane, które uzasadniają podejrzenie popełnienia przestępstwa, lecz nie mogą być „dostatecznie uzasadnione”, gdyż wtedy $\mathrm{w}$ stosunku do takiej osoby należałoby wydać postanowienie o przedstawieniu zarzutów (art. 313 k.p.k.). W związku z tym osobą podejrzaną jest potencjalny sprawca przestępstwa - osoba, wobec której istnieje uzasadnione podejrzenie, iż popełniła czyn zabroniony i dlatego też są wobec niej przeprowadzane czynności procesowe przewidziane przepisami prawa $\mathrm{w}$ celu sprawdzenia zasadności podejrzenia. Trzeba zwrócić uwagę, że chociaż Kodeks postępowania karnego stawia wymóg istnienia uzasadnionego podejrzenia popełnienia przestępstwa w stosunku do osoby podejrzanej jedynie w przypadku czynności procesowej zatrzymania (art. $244 \S 1,1 \mathrm{a}$ i 1b k.p.k.) ${ }^{17}$, to należy uznać, iż zawsze, kiedy w przepisach jest mowa o osobie podejrzanej, musi wystąpić uzasadnione podejrzenie popełnienia przez nią przestępstwa ${ }^{18}$. Należy podkreślić, że jego brak spowodowałby możliwość praktycznie dowolnego stosowania, wobec jakiejkolwiek osoby, przepisów o czynnościach, które mogą być wykonywane w stosunku do osób podejrzanych. Dlatego też niezbędne jest zaistnienie materialnoprawnej przesłanki w postaci „uzasadnionego podejrzenia popełnienia przestępstwa", aby ktoś został osobą podejrzaną w ujęciu polskiej procedury karnej.

Kryterium odróżniającym osobę podejrzaną od podejrzanego jest brak przedstawienia zarzutów (element formalny) oraz rodzaj uzasadnionego podejrzenia popełnienia przestępstwa ${ }^{19}$, które $\mathrm{w}$ przypadku podejrzanego musi być już dostatecznie uzasadnione. Wobec tego uzyskanie statusu osoby podejrzanej w procesie karnym zależne będzie od

W: System prawa karnego procesowego. T. VI: Strony i inni uczestnicy postępowania karnego. Red. C. KulesZa. Warszawa 2016, s. 711.

15 T. GrzegorczyK: Kodeks postępowania karnego oraz ustawa o świadku koronnym. Komentarz. Warszawa 2008, s. 241; R. KoPER: Prawo do obrony osoby podejrzanej. Prok. i Pr. 2016, nr 2, s. 18-19.

16 Wyrok SA we Wrocławiu z dnia 3 marca 2016 r., II AKa 35/16, LEX Omega nr 2023602.

17 Odmiennie: R.A. Stefański: Prawo do..., s. 300.

18 Tak też: M. KLejNowsKa: Oskarżony jako osobowe źródło informacji o przestępstwie. Kraków 2004, s. 19-20.

19 A. Murzynowski: Faktycznie podejrzany..., s. 37; M. KlejnowsKa: Osoba podejrzana..., s. 41; A. CzAPIgo: Osoba podejrzana..., s. 45; P. Lewczyк: Nabycie prawa do posiadania obrońcy a instytucja przedstawienia zarzutów. Pal. 2011, nr 3-4, s. 71; K. EichstaedT. W: B. AugustyniaK et al.: Kodeks postępowania karnego. Komentarz. T. I. Warszawa 2013, s. 336. 
wystąpienia przesłanki uzasadnionego podejrzenia popełnienia danego czynu zabronionego. Nie można przy tym zgodzić się z poglądem, że w Kodeksie postępowania karnego istnieją różne znaczenia pojęcia „osoby podejrzanej”20, ponieważ jedynie z niektórych przepisów można wyciągnąć wniosek, jakie są przesłanki uzyskania statusu osoby podejrzanej. Trzeba uznać, że ustawodawca posłużył się w Kodeksie postępowania karnego jednym pojęciem „osoby podejrzanej”, które należy rozumieć zawsze identycznie, mimo że nie wprowadzono jego definicji legalnej. Nie ma bowiem żadnych podstaw do nadawania temu samemu pojęciu występującemu $\mathrm{w}$ jednym akcie prawnym odmiennych znaczeń językowych.

Wobec braku definicji legalnej „osoby podejrzanej” trzeba podjąć próbę skonstruowania jej w oparciu o elementy negatywne. W ten sposób można nazwać osobą podejrzaną tą, w stosunku do której nie wydano jeszcze postanowienia o przedstawieniu zarzutów lub też której nie przesłuchano $\mathrm{w}$ charakterze podejrzanego $\mathrm{w}$ związku z przedstawieniem zarzutu. Niemniej jednak taka definicja jest zbyt ogólna i w związku z tym należałoby ograniczyć jej zakres poprzez dodanie elementów pozytywnych - czy to wskazanie, że przeciwko takiej osobie organ procesowy prowadzi czynności śledcze ${ }^{21}$, czy to przez określenie, że jest to osoba, co do której istnieją dane uzasadniające podejrzenie popełnienia przestępstwa ${ }^{22}$. Poza tym można by określić, że jest to osoba, wokół której koncentrują się określone działania organów ścigania wyszczególnione w przepisach ${ }^{23}$ w celu zdobycia dowodów, pozwalających na uprawdopodobnienie popełnienia przez nią czynu zabronionego ${ }^{24}$. A zatem osobą podejrzaną będzie ta osoba, wobec której nie zostało jeszcze wydane postanowienie o przedstawieniu zarzutów (i nie przesłuchano jej w charakterze podejrzanego), lecz organy procesowe koncentrują wokół niej określone czynności śledcze lub działania, gdyż istnieją dane uzasadniające podejrzenie popełnienia przez nią przestępstwa ${ }^{25}$, lecz niestanowiące jeszcze wystarczającej podstawy do przedstawienia zarzutów.

W tym miejscu podkreślenia wymaga to, że przedstawiciele doktryny, definiując „osobę podejrzaną”, posługują się raz „przypuszczeniem”, a raz „podejrzeniem” popełnienia przestępstwa, co może powodować

20 A.M. Tęcza-PacioneK: Pojęcie osoby podejrzanej i jej uprawnienia. Prok. i Pr. 2011, nr 11, s. 57.

${ }^{21}$ F. Prusak: Faktycznie podejrzany..., s. 33.

22 A. Murzynowski: Faktycznie podejrzany..., s. 39; R.A. Stefański: Prawo do..., s. 300.

23 P. Hofmański, E. SAdziK. K. ZgryzeK: Kodeks postępowania karnego. T. I: Komentarz..., s. 483.

24 A. Czapigo: Osoba podejrzana..., s. 45.

25 Podobnie A.M. TęCZA-Paciorek: Pojęcie osoby podejrzanej..., s. 60. 
pewne implikacje $\mathrm{w}$ sferze powszechnego odbioru definicji - $\mathrm{w}$ razie przyjęcia jednego z tych określeń ${ }^{26}$. Trafnie wskazuje się bowiem, że przypuszczenie, w odróżnieniu od podejrzenia, to stan subiektywny, w którym tylko zakłada się możliwość, iż konkretna osoba może być sprawcą czynu ${ }^{27}$. I chociaż znaczenia językowe obu tych pojęć są podobne, to należałoby, $\mathrm{w}$ związku z łączeniem przypuszczenia $\mathrm{z}$ subiektywizacją $\mathrm{w}$ odbiorze, operować „zasadnością podejrzenia” ${ }^{28}$, mimo że w przepisie art. $244 \S 1$ i 1a k.p.k. posłużono się pojęciem „przypuszczenia”. Dlatego też należy postulować zmianę art. 244 § 1 i 1a k.p.k. w ten sposób, by zastąpić słowo „przypuszczenie” właśnie „podejrzeniem”, ujednolicając nazewnictwo w obrębie jednego aktu prawnego, jakim jest Kodeks postępowania karnego, zwłaszcza że w przepisie art. $313 \S 1$ k.p.k. jest już mowa o „podejrzeniu".

Elementami definicji „osoby podejrzanej” będą: uzasadnione podejrzenie popełnienia przestępstwa oraz podjęcie próby jego potwierdzenia, wobec istnienia takiego podejrzenia ${ }^{29}$. W związku z tym osobą podejrzaną jest ta osoba, w stosunku do której organy ścigania stwierdzą (na podstawie zgromadzonych dowodów oraz materiałów operacyjnych) zaistnienie uzasadnionego podejrzenia, iż popełniła czyn zabroniony, oraz podejmą wobec niej takie czynności, które zmierzać będą do potwierdzenia istniejącego stanu podejrzenia.

Trzeba wskazać, że w doktrynie pojawiły się również propozycje wprowadzenia do Kodeksu postępowania karnego definicji legalnej pojęcia „osoby podejrzanej”, aby w ten sposób lepiej chronić prawa takiego podmiotu. Należy bowiem zauważyć, iż czynności wykonywane wobec osoby podejrzanej ingerują w podstawowe wolności obywatelskie ${ }^{30}$, dlatego też, skoro organy procesowe podejmują określone działania wobec niej celem weryfikacji przypuszczenia popełnienia przestępstwa, należałoby zawrzeć definicję legalną takiego pojęcia, tak jak „oskarżonego” czy też „podejrzanego”. Proponuje się więc uznanie osoby podejrzanej jako tej, wobec której zachodzi faktyczne podejrzenie popełnienia przestępstwa, i skierowanie przez organy procesowe, po wszczęciu postępowania przy-

${ }^{26}$ I. DziUgiet: Sytuacja prawna..., s. 330.

27 T. GrzegorczyK: Kodeks postępowania..., s. 241.

${ }^{28}$ Odmiennie: W. Posnow. W: Postępowanie karne. Część ogólna. Red. Z. ŚwIDA. Warszawa 2008, s. 195; R.A. STEFAŃsKI: Zatrzymanie osoby podejrzanej o popetnienie przestępstwa z użyciem przemocy na szkodę osoby wspólnie zamieszkujacej. W: Funkcje procesu karnego. Ksiega jubileuszowa Profesora Janusza Tylmana. Red. T. Grzegorczyк. Warszawa 2011, s. 143.

${ }^{29}$ G. Krzysztofiuk: Prawo do obrony osoby podejrzanej..., s. 164.

30 I. Dziugiet: Sytuacja prawna..., s. 330-331; R.A. Stefański: Prawo do..., s. 300-301; A. BAJ: Czy osoba..., s. 91; podobnie: M.R. JAsIŃsKa: Źródła informacji..., s. 171. 
gotowawczego, czynności na jej ściganie ${ }^{31}$. W związku z tym pojawia się propozycja dodania $\S 4$ do art. 71 k.p.k. w brzmieniu: „Osobą podejrzana jest osoba, co do której istnieje uzasadnione podejrzenie, że popełniła przestępstwo i podjęto wobec niej czynności zmierzające do jej ściągania”32, albo: „Osoba podejrzana to każda osoba, w stosunku do której zachodzi dostateczne podejrzenie popełnienia przez nią przestępstwa, ale nie przedstawiono tej osobie w związku z przesłuchaniem żadnych zarzutów"33. Trzeba uznać, że sama propozycja wprowadzenia definicji legalnej „osoby podejrzanej” do Kodeksu postępowania karnego jest godna rozważenia ${ }^{34}$, gdyż w ten sposób nie tylko wskazano by wprost na przesłanki uzyskania statusu osoby podejrzanej, ale również można by było zapewnić jej lepszą ochronę prawną. W związku z tym należy rozważyć wprowadzenie definicji legalnej pojęcia „osoby podejrzanej”, zwłaszcza że wobec takiego uczestnika procesu karnego wykonywanych jest wiele czynności procesowych, często ingerujących w jej prawa i wolność. Taka definicja legalna pozwoliłaby również na jednoznaczne wskazanie, kiedy ktoś uzyskiwałby status osoby podejrzanej.

\section{5.}

W języku potocznym podejrzanym jest osoba, na którą padło podejrzenie o coś, posądzona o $\cos ^{35}$, ewentualnie: budząca podejrzenie, nieufność, niepewna, wątpliwa, niebezpieczna ${ }^{36}$. W języku polskim przez podejrzanego rozumie się więc osobę, która jest podejrzewana o popełnienie jakiegoś czynu. Natomiast w języku prawnym podejrzanym nazwana jest osoba, w stosunku do której wydano postanowienie o przedstawieniu zarzutów albo której bez wydania takiego postanowienia postawiono zarzut w związku z przystąpieniem do przesłuchania

31 A. BAJ: Czy osoba..., s. 91.

32 R.A. StefańsKi: Prawo do..., s. 301.

33 P. Czarnecki: Czy osobie podejrzanej przystuguje prawo do obrony? Przyczynek do krytycznej analizy zagadnienia $w$ kontekście obowiązk poddania tej osoby badaniu alkomatem. W: Prawo do obrony: teoria a rzeczywistość. Red. A. ŚWIATŁowsKi. Kraków 2012, s. 87.

${ }^{34} \mathrm{Za}$ taką definicją opowiadają się m.in.: A.M. Tęcza-PacıoreK: Pojęcie osoby podejrzanej..., s. 72; P. LeWCZYK: Nabycie prawa..., s. 76; S. SteInBorn, A. WĄSEK-WiadereK: Moment uzyskania statusu biernej strony postępowania karnego z perspektywy konstytucyjnej i międzynarodowej. W: Wokół gwarancji wspótczesnego procesu karnego. Księga jubileuszowa Profesora Piotra Kruszyńskiego. Red. M. Rogacka-Rzewnicka, H. GrajewsKa-KraczKowska, B.T. BIEŃKowsKa. Warszawa 2015, s. 447.

35 Stownik języka polskiego. T. 6: P-Prę. Red. W. Doroszewski. Warszawa 1964, s. 626.

${ }^{36}$ Nowy słownik języka polskiego. Red. E. Sobol. Warszawa 2003, s. 684. 
w charakterze podejrzanego (art. 71 § 1 k.p.k.). Trzeba także zwrócić uwagę, że w Kodeksie postępowania karnego z 1969 r. podejrzanym była tylko ta osoba, co do której wydano postanowienie o przedstawieniu zarzutów (art. $61 \S 1$ k.p.k. z 1969 r.), chociaż istniała także możliwość przesłuchania osoby podejrzanej $\mathrm{w}$ charakterze podejrzanego (art. 276 § 1 k.p.k. z 1969 r.). Jednakże ówczesny kodeks nie przyznawał wprost takiej osobie podejrzanej, przesłuchanej $\mathrm{w}$ charakterze podejrzanego, statusu podejrzanego, lecz nazywano ją wtedy właśnie osobą „faktycznie podejrzaną", której przysługiwały takie same gwarancje jak podejrzanemu. Tym samym w aktualnym stanie prawnym ówczesny „faktycznie podejrzany” (z Kodeksu postępowania karnego z 1969 r.) „stał się” już podejrzanym.

W polskim procesie karnym można uzyskać status podejrzanego $\mathrm{w}$ dwóch niezależnych od siebie przypadkach, opisanych w treści art. 71 $\S 1$ k.p.k. (z momentem wydania postanowienia o przedstawieniu zarzutów lub postawienia zarzutu bez wydania takiego postanowienia w związku z przystąpieniem do przesłuchania w charakterze podejrzanego). Wydanie postanowienia o przedstawieniu zarzutów ma miejsce w sytuacji opisanej w art. $313 \S 1$ k.p.k. Natomiast przystąpienie do przesłuchania $\mathrm{w}$ charakterze podejrzanego następuje $\mathrm{w}$ dochodzeniu $\mathrm{w}$ niezbędnym zakresie (art. 308 § 2 k.p.k.), w przypadku prowadzenia postępowania przygotowawczego $\mathrm{w}$ postaci dochodzenia (art. 325g § 1 k.p.k.) oraz w postępowaniu przyspieszonym (art. 517c $\$ 1$ k.p.k.). Tym samym uzyskanie statusu podejrzanego łączy się albo z wydaniem odpowiedniego orzeczenia przez właściwe organy, albo ze szczególnym trybem procesu karnego, gdzie nie jest konieczne takie działanie. Trzeba podkreślić, iż ustawodawca wprost określił przesłanki uzyskania statusu podejrzanego, formułując formalne kryteria, na podstawie których można określić, kiedy ktoś staje się tą bierną stroną procesową.

Z pierwszą sytuacją, kiedy ktoś staje się podejrzanym, mamy do czynienia w przypadku wydania postanowienia o przedstawieniu zarzutów. Z kolei same przesłanki wydania takiego orzeczenia oraz czynności, które są konieczne do tego, aby można było stwierdzić, że takie orzeczenie zostało wydane, opisano w przepisach art. 313 § 1 i 313 § 3 k.p.k. W związku z tym pojęcie „podejrzanego" łączy się z czynnością procesową wydania postanowienia o przedstawieniu zarzutów konkretnej osobie, gdyż od chwili wydania takiego orzeczenia ktoś staje się podejrzanym w ujęciu Kodeksu postępowania karnego.

Przesłanką materialnoprawną wydania postanowienia o przedstawieniu zarzutów są dane dostatecznie uzasadniające podejrzenie, że czyn popełniła określona osoba. Oznacza to, że musi zaistnieć taka podstawa faktyczna, która pozwala na wydanie postanowienia o przedstawieniu 
konkretnych zarzutów określonej osobie ${ }^{37}$. Zaistnieje ona wtedy, gdy stan zebranego materiału dowodowego wskaże co najmniej na to, iż według jednej z wersji wydarzeń, opartej na sprawdzalnych i prawidłowo zebranych dowodach, można będzie wyciągnąć wniosek, że doszło do popełnienia czynu zabronionego przez konkretną osobę ${ }^{38}$. Tym samym na podstawie zgromadzonego materiału dowodowego można skonkretyzować czyn przestępny zarzucany danej osobie i podać jego kwalifikację prawną ${ }^{39}$. Trzeba zwrócić przy tym uwagę, że przesłanka materialnoprawna wydania postanowienia o przedstawieniu zarzutów określa pewne ustawowe minimum takich danych, które pozwalają na wyciągnięcie wniosku o przypuszczeniu, że czyn zabroniony popełniła określona osoba.

Poza przesłanką materialnoprawną przedstawienia zarzutów istnieją inne elementy będące składnikami instytucji przedstawienia zarzutów, którymi są: sporządzenie postanowienia, jego ogłoszenie i przesłuchanie podejrzanego, poprzedzone informacją o uprawnieniach procesowych ${ }^{40}$. Dlatego też, gdy dane istniejące $\mathrm{w}$ chwili wszczęcia śledztwa lub zebrane $\mathrm{w}$ jego toku uzasadniają dostatecznie podejrzenie, że czyn popełniła określona osoba, sporządza się postanowienie o przedstawieniu zarzutów, by następnie ogłosić je i przesłuchać podejrzanego (art. $313 \S 1$ k.p.k.), jednocześnie informując go o przysługujących mu uprawnieniach w związku z wydaniem takiego orzeczenia (art. 313 § 3 k.p.k.).

Wobec powyższego pojawia się pytanie, w którym momencie ktoś staje się podejrzanym w ujęciu polskiej procedury karnej. Jak wynika bowiem z treści art. 71 § 1 k.p.k., następuje to dopiero z momentem wydania postanowienia o przedstawieniu zarzutów. Z kolei art. 313 § 1 k.p.k. określa czynność sporządzenia postanowienia o przedstawieniu zarzutów oraz inne elementy instytucji przedstawienia zarzutów. Wobec treści powołanych przepisów pojawiły się w doktrynie wątpliwości, czy pojęcie „wydania” jest tożsame ze „sporządzeniem”41 czy też ze „sporządzeniem

${ }^{37}$ R.A. Stefański. W: J. Bratoszewski et al.: Kodeks postępowania karnego. Komentarz. T. II. Warszawa 2004, s. 377.

${ }^{38}$ Uchwała SN z dnia 29 czerwca 2007 r., SNO 38/07, LEX Omega nr 471799.

39 D. TARNOWSKA: Różnice między dochodzeniem a śledztwem $w$ polskim procesie karnym. Szczecin 2009, s. 231.

40 M. CIEślak: Postępowanie karne. Zarys instytucji. Warszawa 1982, s. 88-89; S. Stachowiak. W: T. NowaK, S. Stachowiak: Prawo karne procesowe. Dynamika postępowania. Poznań-Bydgoszcz 1999, s. 37; A. GereckA-ŻoŁyńsKa: Przedstawienie zarzutu podejrzanemu $w$ świetle dyrektywy rzetelnego procesu. W: Prawo wobec wyzwań wspótczesności. Red. P. Wiliński. Poznań 2004, s. 296; J. Tylman. W: T. GrzegorczyK, J. Tylman: Polskie postępowanie karne..., s. 624; K.T. BorATYŃsKA. W: K.T. BoRATYŃsKA et al.: Kodeks postępowania karnego. Komentarz. Warszawa 2012, s. 670.

${ }^{41}$ Tak m.in.: A. KafTaL: O ponownym wszczęciu prawomocnie umorzonego postępowania przygotowawczego. „Służba MO” 1964, nr 2, s. 154; F. PrusaK: Elementy przedstawienia 
i ogłoszeniem”42, a może „wydanie” i „ogłoszenie” to dwa różne poję$\mathrm{cia}^{43}$.

Abstrahując jeszcze od odpowiedzi na pytanie o wzajemny zakres tych dwóch pojęć, na początku należy wyjaśnić, czym jest sporządzenie, a czym wydanie orzeczenia. I tak w języku polskim „sporządzać” oznacza: wykonywać ${ }^{44}$, przygotowywać ${ }^{45}$, robić $\cos ^{46}$. Tak więc sporządzeniem będzie przygotowanie, zrobienie. $Z$ kolei wydanie ma bardzo wiele znaczeń, lecz trzeba się ograniczyć jedynie do tych kilku, które mogłyby mieć zastosowanie $\mathrm{w}$ omawianej kwestii. I tak $\mathrm{w}$ języku potocznym oznacza: ogłosić coś drugiemu w formie publikacji ${ }^{47}$, podać do wiadomości ogółu ${ }^{48}$ lub powiadomić o czymśs ${ }^{49}$. Znaczenie czasownika „wydawać” $w$ języku polskim jest związane z czynnością ogłoszenia, ujawnienia czegoś, czy to jednej osobie, czy ogółowi ludzi. Pojęcia „sporządzenie” i „wydanie”s0 w języku polskim mają odmienne znaczenia, i tak też należy je traktować na gruncie polskiej procedury karnej, skoro przepisy Kodeksu postępowania karnego posługują się nimi oboma, i to w różnych kontekstach ${ }^{51}$. Nie ma bowiem żadnych podstaw, aby te dwa pojęcia rozumieć tak samo.

W związku z powyższym trzeba odróżnić czynność sporządzenia postanowienia o przedstawieniu zarzutów od jego wydania ${ }^{52}$. I tak, sporzą-

zarzutów w procesie karnym. „Służba MO” 1970, nr 1, s. 21; T. GrzegorczYK: Instytucja przedstawienia zarzutów w postępowaniu uproszczonym. ZNUŁ 1974, nr 106, s. 43.

42 Tak m.in.: L. Penner: O zmianie przepisów postępowania karnego. NP 1956, nr 2, s. 40; Z. MŁYNARCZYK: O kilku zagadnieniach karno-procesowych na tle praktyki. NP 1961, $\mathrm{nr}$ 4, s. 513-514; S. Waltoś: Model postępowania przygotowawczego na tle prawnoporównawczym. Warszawa 1968, s. 513-514.

${ }^{43}$ Tak m.in.: C. Golı: Wydanie postanowienia o przedstawieniu zarzutów. Prok. i Pr. 2014, nr 9, s. 104-105.

${ }^{44}$ Nowy stownik..., s. 945.

45 Stownik wspótczesnego języka polskiego. Red. B. DunAJ. Warszawa 1996, s. 1047.

46 Słownik języka polskiego. T. 8: S-Ś. Red. W. DoroszewsKi. Warszawa 1966, s. 595.

47 Stownik języka polskiego. T. III: R-Z. Red. M. SzYMCZAK. Warszawa 1992, s. 792.

48 Stownik języka polskiego. T. 9: T-Wyf. Red. W. Doroszewski. Warszawa 1967, s. 1454.

49 Stownik wspótczesnego..., s. 1263.

${ }^{50}$ Szerzej na temat poglądów w doktrynie i orzecznictwie na temat zakresu pojęcia „wydanie” zob. C. GoliK: Wydanie postanowienia..., s. 86-101.

51 Tak też: R.A. Stefański: Skuteczność przedstawienia zarzutów. Prok. i Pr. 2013, nr 6, s. 22; C. GolIK: Wydanie postanowienia..., s. 101; odmiennie J. KasIURA: Moment wszczęcia postępowania przeciwko osobie. „Prokurator” 2011, nr 2, s. 74.

52 Tak też wskazuje się w doktrynie - zob. m.in.: F. PrusaK: Pociagnięcie podejrzanego do odpowiedzialności w procesie karnym. Warszawa 1973, s. 80; J. KasIURA: Moment wszczęcia..., s. 66-67; P. LeWCZYK: Nabycie prawa..., s. 68-69; P. HofMAŃsKI, E. SADZIK, K. ZGRYZEK: Kodeks postępowania karnego. T. I: Komentarz..., s. 481; A. LudwiczeK: Wszczęcie postępowania przeciwko osobie jako moment przerwania biegu terminu przedawnienia karalności. „Iustitia” 2012, nr 2, s. 95; P.K. SowIŃsKI: Uprawnienia składające się na prawo oskarżonego do obrony. Uwagi na tle czynności oskarżonego oraz organów procesowych. Rzeszów 2012, 
dzenie jest czynnością techniczną, polegającą na spisaniu orzeczenia ${ }^{53}$ (postanowienia) - uzewnętrznianiu woli organu procesowego o przedstawieniu konkretnych zarzutów określonej osobie. Tym samym sporządzeniem postanowienia o przedstawieniu zarzutów będzie po prostu jego spisanie. Z kolei podstawowe składniki postanowienia określa przepis art. $94 \S 1$ pkt 1-5 k.p.k. Ponadto zawiera ono też wskazanie podejrzanego oraz dokładne określenie zarzucanego mu czynu i jego kwalifikacji prawnej (art. $313 \S 2$ k.p.k.). Natomiast wydanie postanowienia o przedstawieniu zarzutów to złożona czynność procesowa, na którą generalnie składają się czynności obowiązkowe: sporządzenie postanowienia o przedstawieniu zarzutów, ogłoszenie go i przesłuchanie (poprzedzone pouczeniem o prawach i obowiązkach) ${ }^{54}$. Poza tym czynność wydania takiego orzeczenia może zawierać również przedstawienie ustnych podstaw zarzutów oraz sporządzenie uzasadnienia postanowienia i doręczenie go. Elementy te są z kolei fakultatywne (czynności uzupełniające), gdyż nie muszą zawsze występować, będąc zależne od woli samego podejrzanego. W razie więc żądania podejrzanego stanowią one czynności składające się na wydanie postanowienia o przedstawieniu zarzutów. Ponadto trzeba zwrócić uwagę, iż ustawodawca zdecydował się wprowadzić jeszcze jedną sytuację, w której, mimo braku wszystkich niezbędnych czynności do wydania postanowienia o przedstawieniu zarzutów, będzie ono miało miejsce. Mianowicie z treści przepisu art. 313 § 1 k.p.k. wynika, że jeżeli ogłoszenie postanowienia lub przesłuchanie podejrzanego nie jest możliwe z powodu jego ukrywania się lub nieobecności w kraju, to sporządza się jedynie postanowienie. Tym samym $\mathrm{w}$ razie zaistnienia przesłanki materialnoprawnej wydania postanowienia o przedstawieniu zarzutów czynność ta będzie się ograniczała tylko do sporządzenia orzeczenia. Należy wskazać, że jest to słuszne rozwiązanie, gdyż pozwala na prowadzenie postępowania przygotowawczego wobec osoby, która celowo ukrywa się przed organami ścigania.

s. 67; oraz w orzecznictwie - zob. m.in.: postanowienie SN z dnia 24 kwietnia 2007 r., IV KK 31/07, LEX Omega nr 262649; postanowienie SN z dnia 16 stycznia 2009 r., IV KK 256/08, LEX Omega nr 486201.

53 Tak też m.in.: F. Prusak: Pociagnięcie podejrzanego do odpowiedzialności..., s. 79-80; R.A. Stefański: Glosa do postanowienia SN z 16 stycznia 2009 r., IV KK 256/08. Prok. i Pr. 2009, nr 9, s. 156; Z. Muras: Wyjaśnienia oskarżonego..., s. 44; P. LewczYK: Nabycie prawa..., s. 69; M. BŁońsкI: Wyjaśnienia oskarżonego..., s. 54; A. LuDWICzeK: Wszczęcie postępowania..., s. 98.

${ }^{54}$ K. WoźnIEwsKi: Glosa do postanowienia SN z 24 kwietnia 2007 r., IV KK 31/07. GSP 2008, nr 1, poz. 10, s. 115; J. Tylman. W: T. GrzegorczyK, J. Tylman: Polskie postępowanie karne..., s. 624; R.A. StEFAŃsKi: Glosa do postanowienia..., s. 153; K. EichSTAEDT. W: B. AugustyniaK et al.: Kodeks postępowania karnego... T. I, s. 334; Z. BrodzisZ. W: Z. BrodzIsZ et al.: Kodeks postępowania karnego..., s. 756. 
Na przedstawienie zarzutów składa się szereg czynności, co jednocześnie oznacza, że zakres nazwy „wydanie” jest szerszy niż „sporządzenie” (polegające na spisaniu orzeczenia). $\mathrm{Z}$ brzmienia art. 313 k.p.k. można z kolei wyciągnąć wniosek, że wydanie następuje najwcześniej z chwilą sporządzenia postanowienia o przedstawieniu zarzutów ( $\mathrm{w}$ razie ukrywania się podejrzanego lub jego nieobecności w kraju - art. 313 § 1 k.p.k. $)^{55}$. Ponadto możliwa byłaby taka interpretacja, że skoro do instytucji przedstawienia zarzutów należą fakultatywnie: podanie ustnych podstaw zarzutów i sporządzenie uzasadnienia na piśmie, to w razie zgłoszenia któregokolwiek z tych żądań należałoby o wydanym postanowieniu o przedstawieniu zarzutów mówić dopiero w momencie doręczenia postanowienia. Jednakże taka wykładnia byłaby sprzeczna z przepisem art. $313 \S 3$ k.p.k., w którym jest mowa już o podejrzanym, mimo iż ten zgłosił swoje żądania wynikające z fakultatywnych elementów instytucji przedstawienia zarzutów. Wobec tego nie można wnioskować $\mathrm{w}$ ten sposób, że dana osoba uzyskuje status podejrzanego, kiedy wykonano wobec niej wszystkie czynności instytucji przedstawienia zarzutów, ponieważ podejrzanym jest osoba, wobec której sporządzono i ogłoszono postanowienie o przedstawieniu zarzutó $w^{56}$. Oznacza to, iż wtedy postępowanie $\mathrm{z}$ fazy in rem „wchodzi” w fazę in personam ${ }^{57}$. Takie stanowisko znajduje swoje uzasadnienie także w treści art. 300 § 1 i 301 k.p.k. Gdyby bowiem daną osobę traktować jako podejrzanego dopiero po wykonaniu wszystkich czynności z art. $313 \S 1$ k.p.k., to nie byłaby ona należycie chroniona przez okres do zakończenia ostatniej z nich, a wynikającej z instytucji przedstawienia zarzutów.

W Kodeksie postępowania karnego jest mowa zarówno o czynności sporządzenia, jak i wydania postanowienia o przedstawieniu zarzutów. Natomiast zakres pojęcia „wydania" 58 winien (w kontekście uzyskania statusu podejrzanego) ograniczać się albo do sporządzenia postanowienia

55 Tak też: K. ChatubeK: Podjęcie na nowo czy wznowienie postępowania przygotowawczego $w$ fazie in rem z powodu znikomej społecznej szkodliwości czynu „faktycznie podejrzanego”. „Studia Prawno-Ekonomiczne” 2011, nr 84, s. 64; podobnie w wyroku SA w Katowicach z dnia 18 września 2015 r., II AKa 268/15, LEX Omega nr 1962872.

56 Tak też: R. ŁYczYweK: Prawo oskarżonego do znajomości zarzutów, materiałów $i$ akt sprawy $w$ świetle nowego kodeksu postępowania karnego. NP 1969, nr 7-8, s. 1160; Z. Muras: Wyjaśnienia oskarżonego..., s. 45; J. Kosonoga: Przedstawienie i modyfikacja zarzutów a rola obrońcy. W: Obrońca i petnomocnik $w$ procesie karnym po 1 lipca 2015 r. Przewodnik po zmianach. Red. P. WiLIŃsKI. Warszawa 2015, s. 108.

57 Postanowienie SA w Krakowie z dnia 27 marca 2013 r., II AKz 96/13, LEX Omega nr 1315686.

${ }^{58}$ Szczegółowo na temat interpretacji pojęcia wydania (w tym też w zakresie wykładni językowej) w art. $71 \S 1$ i 313 § 1 k.p.k. zob. J. Kasıura: Moment wszczęcia..., s. 62-74. 
o przedstawieniu zarzutów (w razie niemożności ogłoszenia) ${ }^{59}$, albo do sporządzenia takiego orzeczenia i ogłoszenia ${ }^{60}$. W tych dwóch sytuacjach będzie można dopiero powiedzieć, że dana osoba stała się podejrzanym ${ }^{61}$, mimo iż istnieją jeszcze inne czynności składające się na instytucję przedstawienia zarzutów. Dlatego też słusznie wskazuje się w doktrynie, że różnica między wydaniem a sporządzeniem postanowienia o przedstawieniu zarzutów sprowadza się w zasadzie do jego ogłoszenia ${ }^{62}$. Dodać przy tym należy, iż zasadnie pojawiają się w doktrynie pewne zastrzeżenia co do momentu ogłoszenia postanowienia, gdyż do tej chwili może upłynąć pewien czas, a właśnie do ogłoszenia orzeczenia nie można byłoby mówić o wydanym postanowieniu ${ }^{63}$. Tak więc, aby rozwiązać ten problem, postuluje się, by pojęcie „wydania” było rozumiane jako wynik czynności podejmowanych przez odpowiednie organy procesowe, w następstwie których pojawia się dana decyzja procesowa ${ }^{64}$. A zatem wydaniem w tym przypadku byłoby uzewnętrznienie postanowienia o przedstawieniu zarzutów, polegające na jego przekazaniu do realizacji ${ }^{65}$. Niemniej jednak taka koncepcja, aczkolwiek słuszna, wymagałaby stosownej zmiany przepisów.

Należy zwrócić uwagę na konieczność unikania utożsamiania pojęcia „wydania postanowienia” o przedstawieniu zarzutów w rozumieniu art. 313 k.p.k. $z$ interpretacją takiego pojęcia na gruncie art. $71 \S 1$ k.p.k., zważywszy dodatkowo na to, że pierwsza z tych norm nie używa w ogó-

59 Podobnie: E. KruK: Glosa do wyroku Sądu Najwyższego z 5 marca 2014 r., IV KK 341/13. IN 2016, nr 1, s. 176.

${ }^{60} \mathrm{Na}$ co już zwrócono uwagę w doktrynie - zob. m.in.: R. ŁyCzyweK: Prawo oskarżonego..., s. 1160; Z. Muras: Wyjaśnienia oskarżonego..., s. 45; J. ZAGRodnIK: Metodyka pracy obrońcy i petnomocnika w sprawach karnych i karnych skarbowych. Warszawa 2016, s. 117118; odmiennie Sąd Najwyższy, który wskazał, że z wydanym postanowieniem mamy do czynienia po spełnieniu przesłanek: sporządzenia postanowienia, jego niezwłocznego ogłoszenia i przesłuchania podejrzanego - zob. wyrok z dnia 5 marca 2014 r., IV KK 341/13, LEX Omega nr 1444341.

${ }^{61}$ Tak też m.in.: Z. GostyŃsKI, S. ZABŁocki. W: J. BratoszewsKi et al.: Kodeks postępowania karnego... T. I, s. 513; R.A. STEFAŃSKI: Glosa do postanowienia..., s. 156; P. LEWCZYK: Nabycie prawa..., s. 68-69; P. HoFMAŃsKI, E. SADZIK, K. ZGRYZEK: Kodeks postępowania karnego. T. I: Komentarz..., s. 482; P.K. SowiŃsKI: Uprawnienia składające..., s. 67-68; K. EICHSTAEDT. W: B. AugustyniaK et al.: Kodeks postępowania karnego... T. I, s. 334-335; Z. Brodzisz. W: Z. Brodzisz et al.: Kodeks postępowania karnego..., s. 756; J. Kosonoga. W: System prawa karnego procesowego. T. X: Postępowanie przygotowawcze. Red. R.A. STEFAŃsKI. Warszawa 2016, s. 803-804.

${ }^{62}$ D. TaRnowsKa: Różnice między..., s. 230; P.K. Sowiński: Uprawnienia składajace..., s. 67.

63 A. Ludwiczek: Wszczęcie postępowania..., s. 97.

${ }^{64}$ Ibidem, s. 95.

${ }^{65}$ Ibidem, s. 96. 
le zwrotu „wydanie postanowienia”. Pomimo iż oba omawiane przepisy odnoszą się do wydania postanowienia o przedstawieniu zarzutów, to jednak dotyczą różnych kwestii i znajdują się w dwóch różnych rozdziałach kodeksu ${ }^{66}$.

W związku z powyższymi rozważaniami należy dodać, iż przepis art. 313 k.p.k. określa instytucję przedstawienia zarzutów. Z kolei wydanie postanowienia o przedstawieniu zarzutów z art. $71 \S 1$ k.p.k. nie może być utożsamiane z samym ich przedstawieniem. Słusznie więc podkreślono w orzecznictwie, że przedstawienie zarzutów ma miejsce wtedy, gdy sporządzi się postanowienie o przedstawieniu zarzutów i ogłosi się $\mathrm{je}^{67}$ (względnie w przypadku ukrywania się danej osoby także z chwilą sporządzenia), dlatego też należy odróżnić pojęcia „sporządzenia” i „wydania" postanowienia o przedstawieniu zarzutów (którym jest jego uzewnętrznienie).

Podejrzanym jest także ten, wobec którego przystąpiono do przesłuchania w charakterze podejrzanego. $Z$ pierwszą sytuacją, gdy dana osoba staje się podejrzanym bez wydania wobec niej postanowienia o przedstawieniu zarzutów, mamy do czynienia w art. 308 \$ 2 k.p.k. A zatem w wypadkach niecierpiących zwłoki, w szczególności wtedy, gdy mogłoby to spowodować zatarcie śladów lub dowodów przestępstwa, można w toku czynności wymienionych w art. $308 \S 1$ k.p.k. przesłuchać osobę podejrzaną o popełnienie przestępstwa $\mathrm{w}$ charakterze podejrzanego przed wydaniem postanowienia o przedstawieniu zarzutów, jeżeli zachodzą warunki do wydania takiego orzeczenia.

W przypadku zaistnienia przesłanek uzasadniających przesłuchanie kogoś $\mathrm{w}$ charakterze podejrzanego nie wydaje się postanowienia o przedstawieniu zarzutów, lecz przystępuje się bezpośrednio do przesłuchania takiej osoby. Przesłuchanie rozpoczyna się od informacji o treści zarzutu, a organ wykonujący czynności w niezbędnym zakresie winien poinformować o treści stawianego zarzutu, a więc dokładnie wskazać zarzucany czyn oraz jego kwalifikację prawną. Najistotniejszą czynnością jest przedstawienie treści zarzutu, gdyż od tego momentu należy daną osobę traktować jako podejrzanego ${ }^{68}$. Właśnie z tą chwilą uzyskuje ona status podej-

${ }^{66}$ Słusznie przy tym zwraca się uwagę w doktrynie, iż przepisy art. $71 \S 1$ i 313 $\S 1$ k.p.k. powinny być łącznie odczytywane - zob. P. LewczyK: Nabycie prawa..., s. 69, a przepis art. $71 \S 1$ k.p.k. zawiera tylko ogólną definicję podejrzanego - zob. Z. MuRAs: Wyjaśnienia oskarżonego..., s. 46.

${ }^{67}$ Wyrok SN z dnia 6 lutego 1962 r., IV K 961/60, LEX Omega nr 135554; wyrok SN z dnia 7 listopada 2006 r., IV KK 150/06, LEX Omega nr 295347.

${ }^{68}$ R.A. StefańsKi. W: J. BratoszewsKi et al.: Kodeks postępowania karnego... T. II..., s. 357; T. GrzegorczyK: Kodeks postępowania..., s. 657; Z. Muras: Wyjaśnienia oskarżonego..., s. 46; M. BŁoński: Wyjaśnienia oskarżonego..., s. 33; P. HofmańsKi, E. SAdzIK. K. ZGRYZeK: Kodeks postępowania karnego. T. II: Komentarz..., s. 84. 
rzanego w postępowaniu przygotowawczym. Należy dodatkowo wskazać, że taką osobę należy również pouczyć o przysługujących jej uprawnieniach z przepisów art. 300 § 1 i 301 k.p.k., lecz jest to kolejna czynność wtórna do samego nabycia statusu podejrzanego. Oznacza to, iż od momentu poinformowania o zarzutach, a nie pouczenia o treści uprawnień, może ona korzystać z przysługujących jej praw. Następnie osobę, którą przesłuchuje się w charakterze podejrzanego informuje się o uprawnieniach wynikajaccych z art. 313 \$ k.p.k. (ustnego podania podstaw zarzutów; sporządzenia uzasadniania postanowienia na piśmie).

Kolejna sytuacja, gdy dana osoba staje się podejrzanym bez wydania przeciwko niej postanowienia o przedstawieniu zarzutów, została opisana w art. $325 \mathrm{~g} \$ 1$ k.p.k. Zgodnie z nim w dochodzeniu nie jest wymagane między innymi sporządzenie postanowienia o przedstawieniu zarzutów, chyba że podejrzany jest tymczasowo aresztowany. Przesłuchanie danej osoby zaczyna się od powiadomienia jej o treści zarzutu wpisanego do protokołu przesłuchania, a samą osobę od chwili rozpoczęcia przesłuchania uważa się za podejrzanego (art. 325g § 2 k.p.k.). W dochodzeniu istnieją więc odrębności w instytucji przedstawienia zarzutów, które polegają na odformalizowaniu trybu wydawania postanowienia o przedstawieniu zarzutów. W stosunku do instytucji przedstawienia zarzutów z art. 313 k.p.k. czynność taka w dochodzeniu nie jest związana ze sporządzeniem postanowienia. Oznacza to, że nie spisuje się sentencji orzeczenia, pomimo tego, iż istnieją warunki do sporządzenia postanowienia. Dlatego też zamiast sporządzenia postanowienia o przedstawieniu zarzutów, treść danego zarzutu wpisuje się bezpośrednio do protokołu przesłuchania, co wprost wynika z art. $325 \mathrm{~g} \$ 2 \mathrm{k} . \mathrm{p} . \mathrm{k}$. Treść zarzutu powinna obejmować wskazanie podejrzanego, dokładne określenie zarzucanego mu czynu i jego kwalifikacji prawnej, analogicznie do postanowienia o przedstawieniu zarzutów (art. 313 § 2 k.p.k.). Nie można bowiem różnicować tych dwóch sytuacji mimo odmiennego trybu uzyskiwania statusu podejrzanego, gdyż chodzi w nich o przedstawienie zarzutów, a w dochodzeniu Kodeks postępowania karnego zezwala jedynie na zaniechanie sporządzenia postanowienia. Z kolei interpretacja pojęcia „treść zarzutu” nie może być ograniczona jedynie do jego podstawy faktycznej. Poza tym, aby przedstawić zarzuty, musi zaistnieć dostatecznie uzasadnione podejrzenie, że dany czyn popełniła określona osoba (przesłanka materialnoprawna z art. $313 \S 1$ k.p.k.).

Tryb przedstawienia zarzutów z przepisu art. $325 \mathrm{~g}$ k.p.k. został natomiast wyłączony w stosunku do podejrzanego, który został tymczasowo aresztowany. Należy dodać, iż obecnie, wobec uchylenia z dniem 1 lipca 2015 r. art. 325c k.p.k., w zasadzie nie istnieją ograniczenia podmiotowe w prowadzeniu dochodzeń. 
Przepis art. 325g k.p.k. odnosi się do chwili, w której dana osoba uzyskuje status podejrzanego. Następuje to w momencie rozpoczęcia przesłuchania (od chwili powiadomienia o zarzucie) ${ }^{69}$. Na tle tego przepisu brak jest sporów doktrynalnych dotyczących chwili nabywania statusu podejrzanego. Takiej interpretacji trzeba jednakże przeciwstawić art. $71 \S 1$ k.p.k., określający także moment, w którym uznaje się kogoś podejrzanym (postawienie zarzutu w związku z przystąpieniem do przesłuchania $\mathrm{w}$ charakterze podejrzanego bez wydania postanowienia o przedstawieniu zarzutów). W związku z brzmieniem tych dwóch przepisów (art. $325 \mathrm{~g}$ i $71 \S 1$ k.p.k.) pojawia się pytanie o ich wzajemną relację. Należy podkreślić, że wprawdzie przesłuchanie zwykle rozpoczyna się po ogłoszeniu zarzutu i poinformowaniu o przysługujących uprawnieniach, lecz do tego momentu upływa czas, w którym także należy zapewnić ochronę prawną takiej osobie, która de facto staje się podejrzanym już od chwili przedstawienia jej zarzutu, co wprost wynika z przepisu art. $71 \S 1$ k.p.k. Przepis ten należy jednakże traktować jako normę ogólną w stosunku do szczególnej z art. 325g § 2 k.p.k., gdyż obejmuje ona wszystkie sytuacje „stawania się podejrzanym”. Z kolei art. $325 \mathrm{~g} \$ 2$ k.p.k. odnosi się tylko do specyficznej sytuacji podejrzanego w dochodzeniu. Należałoby wobec tego zastanowić się nad koniecznością ujednolicenia „chwili”, w której dana osoba uzyskuje status podejrzanego. Zwłaszcza że w przepisie art. $325 \mathrm{~g} \S 3$ k.p.k. jest mowa już o podejrzanym, któremu należy umożliwić przygotowanie do obrony. Jednakże wobec brzmienia poprzedniego paragrafu tego przepisu (z którego wynika, iż jako podejrzanego uznaje się osobę od chwili rozpoczęcia przesłuchania) w rzeczywistości takie prawo przysługiwałoby dopiero od momentu przesłuchania, uniemożliwiając tym samym skorzystanie z uprawnien strony procesowej przed rozpoczęciem tej czynności, a po poinformowaniu o treści zarzutu. A przecież może się zdarzyć sytuacja, iż od chwili ogłoszenia zarzutu do momentu przystąpienia do przesłuchania upłynie pewien czas, mimo że czynności te winny następować bezpośrednio po sobie. Taka sytuacja powodowałaby ograniczenie prawa do obrony podejrzanego i w zasadzie uprawnienie z przepisu art. $325 \mathrm{~g} § 3$ k.p.k. byłoby iluzoryczne.

Ostatnia sytuacja, gdy ktoś uzyskuje status podejrzanego bez wydania wobec niego postanowienia o przedstawieniu zarzutów, ma miejsce $\mathrm{w}$ postępowaniu przyspieszonym. W postępowaniu tym moment, w któ-

69 S. Stachowiak. W: K. Marszae, S. Stachowiak, K. Zgryzek: Proces karny..., s. 422; M. Klejnowska et al.: Proces karny. Część szczególna. Red. G. Artymiak, M. Rogalski, Z. Sobolewski. Warszawa-Kraków 2007, s. 37; K. WoźNiewski: Glosa do..., s. 114; T. GrZEgorczYK: Kodeks postępowania..., s. 708; M. BŁoŃsKI: Wyjaśnienia oskarżonego..., s. 70; P.K. SowińsKI: Uprawnienia składajace..., s. 80; R.A. STEFAŃsKI: Skuteczność przedstawienia..., s. 24; Z. BrodzIsz. W: Z. BrodZIsZ et al.: Kodeks postępowania karnego..., s. 795. 
rym dana osoba staje się podejrzanym, jest niezbyt precyzyjnie określony, lecz należy mieć na względzie art. 517c $\$ 2$ k.p.k., który pośrednio wskazuje, kiedy uzyskuje się status podejrzanego. Z literalnego brzmienia tego przepisu wynika, że to już podejrzanego poucza się o uprawnieniach, co oznacza, iż status ten dana osoba uzyskała już wcześniej. Taki wniosek, $\mathrm{w}$ powiązaniu z określeniem, że dochodzenie w postępowaniu przyspieszonym można ograniczyć do przesłuchania osoby podejrzanej w charakterze podejrzanego (art. 517c $\S 1$ k.p.k. ${ }^{70}$, sprawia, że podejrzanym staje się osoba podejrzana $\mathrm{z}$ chwilą poinformowania jej o treści zarzutów. Na marginesie trzeba wskazać, że istnieje również pogląd, iż w postępowaniu przyspieszonym dopiero od chwili przesłuchania winno się daną osobę traktować jako podejrzanego ${ }^{71}$ - zgodnie z art. $325 \mathrm{~g} \S 2$ k.p.k. Pogląd ten wprawdzie trafnie uzasadnia się tym, że przepisy regulujące dochodzenie stosuje się odpowiednio $\mathrm{w}$ postępowaniu przyspieszonym. Jednakże trzeba mieć na względzie, iż z treści art. 517c § 2 k.p.k. wynika, że to już podejrzanego informuje się o uprawnieniach. Dlatego też taka czynność winna mieć miejsce przed przesłuchaniem. Oznacza to, że dana osoba stała się podejrzanym z chwilą poinformowania jej o treści zarzutu.

6.

W języku potocznym oskarżonym jest człowiek postawiony w stan oskarżenia przed sądem ${ }^{72}$, ten, przeciwko któremu wszczęto postępowanie karne ${ }^{73}$. Tym samym w języku polskim oskarżony to osoba, w stosunku do której toczy się postępowanie karne przed sądem, a więc ta, którą postawiono w stan oskarżenia.

Z kolei w polskim Kodeksie postępowania karnego zawarte są dwa pojęcia oskarżonego - w art. 71 § 2 i 71 § 3 k.p.k. I tak, zgodnie $\mathrm{z}$ art. 71 $\S 2$ k.p.k. oskarżonym jest osoba, przeciwko której wniesiono oskarżenie do sądu oraz osoba, w stosunku do której prokurator złożył wniosek o wydanie wyroku skazującego na posiedzeniu w trybie art. $335 \S 1$ k.p.k.

70 T. GrzegorczyK: Nowy model postępowania przyspieszonego w sprawach karnych. Prok. i Pr. 2010, nr 4, s. 25; J. KasIŃsKI: Nowe rozwiazania $w$ zakresie trybu przyspieszonego po nowelizacji Kodeksu postępowania karnego. MoP 2010, nr 20, s. 1114.

${ }^{71}$ P. HofmańsKi, E. SADZIK, K. ZgRYZeK: Kodeks postępowania karnego. T. III: Komentarz do art. 468-682. Red. P. HofmańsKi. Warszawa 2012, s. 147.

72 Stownik współczesnego..., s. 696; Nowy słownik..., s. 611.

73 Stownik języka polskiego. T. 5: Nie-Ó. Red. W. Doroszewski. Warszawa 1963, s. 1129; podobnie: Uniwersalny stownik języka polskiego. T. II: K-Ó. Red. S. DuBIsz. Warszawa 2006, s. 1311. 
albo wniosek o warunkowe umorzenie postępowania karnego. I jest to oskarżony sensu stricte ${ }^{74}$ ('ścisłe ujęcie pojęcia oskarżonego).

Rozważania należy rozpocząć od pierwszej sytuacji, w której dana osoba uzyskuje status oskarżonego, a jest nią moment wniesienia oskarżenia do sądu. W przeciwieństwie do Kodeksu postępowania karnego z 1969 r. w obecnym stanie prawnym określa się chwilę wniesienia oskarżenia jako właściwą do „stania się” oskarżonym, odstępując od poprzedniej regulacji kodeksowej (wniesienie aktu oskarżenia). Takie odmienne uregulowanie nie jest przypadkowe, gdyż wiąże się ze zniesieniem uprawnienia prokuratora do warunkowego umorzenia postępowania karnego na etapie postępowania przygotowawczego i wprowadzeniem właśnie wniosku o warunkowe umorzenie postępowania karnego ${ }^{75}$. Z kolei w Kodeksie postępowania karnego z 1969 r. oskarżonym była tylko ta osoba, przeciwko której wniesiono akt oskarżenia (art. 61 § 2 k.p.k. z 1969 r.), ponieważ prokurator posiadał uprawnienie do warunkowego umorzenia postępowania karnego już na etapie postępowania przygotowawczego (art. 286 k.p.k. z 1969 r.). Oznaczało to, że oskarżonym pod rządami poprzedniej regulacji kodeksowej był ten, przeciwko któremu wniesiono akt oskarżenia do sądu.

Momentem, w którym dana osoba staje się oskarżonym, jest chwila wniesienia oskarżenia do sądu, złożenia wniosku o wydanie wyroku skazującego na posiedzeniu w trybie art. 335 § 1 k.p.k. lub złożenia wniosku o warunkowe umorzenie postępowania karnego ${ }^{76}$. Wniesienie oskarżenia do sądu to nic innego jak przekazanie odpowiedniej skargi do sądu celem wydania rozstrzygnięcia o przedmiocie procesu. Chodzi tutaj zarówno o wniesienie publicznego aktu oskarżenia przez oskarżyciela publicznego (także w przypadku, gdy do niego dołącza wniosek o skazanie bez rozprawy w trybie art. $335 \S 2$ k.p.k.), prywatnego aktu oskarżenia przez oskarżyciela prywatnego ( $\mathrm{w}$ tym też skargi wnoszonej przez policję na

74 W. Daszkiewicz: Prawo karne..., s. 249; K. Marszat. W: K. Marszat, S. Stachowiak, K. ZgryzeK: Proces karny..., s. 189; Z. Gostyński, S. ZabŁocki. W: J. Bratoszewski et al.: Kodeks postępowania karnego... T. I, s. 514; P.K. Sowiński. W: G. ARTYMiak et al.: Proces karny. Część ogólna..., s. 119; T. GrzegorczyK. W: T. GrZegorczyK, J. Tylman: Polskie postępowanie karne..., s. 310; E. SKrętowicz. W: R. KмieciK, E. Skrętowicz: Proces karny. Częśś ogólna, s. 162; P. HofmańsKi, E. SADZIK, K. ZgRYZEK: Kodeks postępowania karnego. T. I: Komentarz..., s. 484; K.T. BORATYŃsKA. W: K.T. BORATYŃsKA et al.: Kodeks postępowania karnego..., s. 200.

${ }^{75}$ Z. GostyŃsKI, S. ZABŁOCKI. W: J. BRATOsZEWsKi et al.: Kodeks postępowania karnego... T. I, s. 514.

76 Z. Muras: Wyjaśnienia oskarżonego..., s. 49; M. BŁońsKI: Wyjaśnienia oskarżonego..., s. 85; P.K. SowIŃsKi: Uprawnienia składające..., s. 103; K. DUDKA. W: K. DUDKA, H. Paluszkiewicz: Postępowanie karne. Warszawa 2016, s. 126; A. Sakowicz. W: System prawa karnego procesowego. T. VI: Strony..., s. 759. 
podstawie art. $488 \S 1$ k.p.k.), jak i subsydiarnego aktu oskarżenia przez oskarżyciela subsydiarnego ${ }^{77}$, a także złożenie wniosku o rozpoznanie sprawy $\mathrm{w}$ postępowaniu przyspieszonym ${ }^{78}$. Tym samym data, w której jedna $\mathrm{z}$ wyżej wymienionych skarg inicjujących postępowanie jurysdykcyjne wpłynęła do sądu, jest tym momentem, w którym można już mówić o oskarżonym. Trzeba przy tym dodać, iż w doktrynie trafnie wskazuje się, że nieprokuratorscy oskarżyciele publiczni także mogą składać wnioski o skazanie bez rozprawy i warunkowe umorzenie postępowania karnego, dlatego też określenie zawarte w art. 71 § 2 k.p.k., iż oskarżonym jest ta osoba, wobec której takie wnioski złożył jedynie prokurator, jest nieuzasadniona ${ }^{79}$. Tym samym należałoby postulować zmianę art. $71 \S 2$ k.p.k. w ten sposób, aby wynikało z niego, że za oskarżonego uważa się osobę, co do której złożono wniosek wskazany w art. 335 § 1 lub wniosek o warunkowe umorzenie postępowania.

Warto zwrócić uwagę, iż w związku z nowelą Kodeksu postępowania karnego, która weszła w życie 1 lipca $2015 \mathrm{r}^{80}$, obecnie w przypadku określonym w art. $335 \S 1$ k.p.k. (skazanie bez rozprawy) składa się, zamiast aktu oskarżenia, wniosek o wydanie na posiedzeniu wyroku skazującego i orzeczenie uzgodnionych kar lub innych środków. Wniosek taki zastępuje więc akt oskarżenia, wywołując takie same skutki w zakresie zmiany pozycji procesowej podejrzanego na oskarżonego ${ }^{81}$. Tym samym obecne precyzyjne wskazanie (nowelą, która weszła w życie 15 kwietnia 2016 r.) w przepisie art. $71 \S 1$ k.p.k. chwili złożenia wniosku z art. 335 § 1 k.p.k. jako momentu, w którym dana osoba uzyskuje status oskarżonego, nie było konieczne ${ }^{82}$, choć rzeczywiście zmiana ma charakter uściślający. A to

77 Z. Muras: Wyjaśnienia oskarżonego..., s. 49; M. BŁońskI: Wyjaśnienia oskarżonego..., s. 84-85; P. HofMAŃski, E. SADZiK, K. ZgryzeK: Kodeks postępowania karnego. T. I: Komentarz..., s. 484; S. Steinborn, J. Grajewski. W: J. GrajewsKi, L.K. PAPrZycki, S. SteInborn: Komentarz aktualizowany do art. 1-424..., teza 5 do art. 71 k.p.k.; M.R. JAsIŃsKA: Źródta informacji..., s. 171.

78 T. GrzegorczYK: Wniosek o rozpoznanie sprawy $w$ postępowaniu przyspieszonym jako surogat aktu oskarżenia. W: Skargowy model procesu karnego. Ksiega ofiarowana prof. Stanisławowi Stachowiakowi. Red. A. GereckA-ŻoŁYńsKa. Poznań 2008, s. 103-104; K. ZGRYZEK: Skargi zastępujace akt oskarżenia w polskim procesie karnym. W: Skargowy model procesu karnego..., s. 417; K. EICHSTAEDT: Postępowania szczególne w polskim procesie karnym. Warszawa 2010, s. 254; S. Steinborn, J. GrajeWsKi. W: J. GrajeWsKi, L.K. PAPrzycKi, S. STEINBorn: Komentarz aktualizowany do art. 1-424..., teza 5 do art. 71 k.p.k.

${ }^{79}$ Szerzej na ten temat zob. K. DudKa. W: K. DudKa, H. Paluszkiewicz: Postępowanie karne..., s. 126-127.

${ }^{80}$ Ustawa z dnia 20 lutego 2015 r. o zmianie ustawy - Kodeks karny oraz niektórych innych ustaw, Dz.U. 2015, poz. 396.

81 Z. Brodzisz. W: Z. BrodzISZ et al.: Kodeks postępowania karnego..., s. 836.

82 Odmiennie: K. Eichstaedt. W: B. AugustyniaK et al.: Kodeks postępowania karnego. Komentarz do zmian. Red. D. ŚwIECKI. Warszawa 2016, s. 64. 
dlatego, że oczywiste było, iż złożenie takiego wniosku stanowiło wniesienie oskarżenia do sądu.

Jak już wcześniej wskazano, dzień, w którym jedna z wyżej wymienionych skarg została złożona w sądzie, jest tym momentem, od którego można określać daną osobę już jako oskarżoną. Warto także dodać, że najczęściej oskarżonym będzie ten, kto już wcześniej występował w postępowaniu przygotowawczym $\mathrm{w}$ roli podejrzanego, chociaż nie zawsze tak jest. Przypadek taki ma miejsce np. w razie wniesienia subsydiarnego aktu oskarżenia, gdzie niekoniecznie postępowanie przygotowawcze musi się toczyć w fazie in personam, przeciwko konkretnej osobie. Taka sytuacja może wystąpić również w przypadku prywatnego aktu oskarżenia.

Akt oskarżenia i wniosek o skazanie muszą odpowiadać warunkom określonym w art. 332 i 333 k.p.k. Z kolei w razie wystąpienia braków formalnych aktu oskarżenia (wniosku o skazanie) prezes sądu zwraca go oskarżycielowi w celu usunięcia tych braków w terminie 7 dni (art. 337 $\S 1$ k.p.k.), a ten, jeżeli nie składa zażalenia na takie zarządzenie, zobowiązany jest wnieść ponownie akt oskarżenia po uzupełnieniu lub poprawie (art. 337 § 3 k.p.k.). Takie uregulowanie nie ma większego znaczenia dla statusu oskarżonego. To, że akt oskarżenia zostanie zwrócony celem uzupełnienia braków formalnych, nie powoduje, że zmienia się sytuacja prawna oskarżonego, który nadal nim pozostaje, gdyż sprawa do momentu wniesienia $\mathrm{w}$ terminie poprawionego aktu oskarżenia zawisła przed sądem $^{83}$. Z kolei $\mathrm{w}$ przypadku przekroczenia terminu ustaje zawisłość sprawy przed sądem ${ }^{84}$.

Natomiast inaczej wygląda sytuacja $\mathrm{w}$ przypadku przekazania przez sąd sprawy prokuratorowi celem uzupełnienia śledztwa lub dochodzenia uregulowanego $\mathrm{w}$ art. $344 \mathrm{a} \S 1$ k.p.k. (zaistnienia przesłanki istotnych braków postępowania, zwłaszcza potrzeby poszukiwania dowodów, gdy dokonanie niezbędnych czynności przez sąd powodowałoby znaczne trudności), który to przepis ponownie, w tym samym brzmieniu, wprowadzono nowelą do Kodeksu postępowania karnego ${ }^{85} \mathrm{z}$ dniem 15 kwietnia 2016 r. W związku z tym słusznie w doktrynie wskazywano, na gruncie poprzedniego stanu prawnego, sprzed 1 lipca 2015 r. (a które to poglą-

83 R.A. STEFAŃsKI: Formalna kontrola aktu oskarżenia $w$ nowym kodeksie postępowania karnego. Prok. i Pr. 1998, nr 9, s. 39; B. DzIDuszko: Postępowanie w przedmiocie kontroli formalnej aktu oskarżenia na podstawie art. 337 \$ 1 k.p.k. „Studia Iuridica Lublinensia” 2011, nr 16, s. 219; L.K. Paprzycki, S. Steinborn, J. Grajewski. W: J. GrajeWski, L.K. Paprzycki, S. STEINBorn: Komentarz aktualizowany do art. 1-424..., teza 11 do art. 337 k.p.k.

${ }^{84}$ P. HofMAŃsKi, E. SADZIK, K. ZgrYZeK: Kodeks postępowania karnego. T. II: Komentarz..., s. 337 .

${ }^{85}$ Ustawa z dnia 11 marca 2016 r. o zmianie ustawy - Kodeks postępowania karnego oraz niektórych innych ustaw, Dz.U. 2016, poz. 437. 
dy zachowują aktualność obecnie), że decyzja o zwrocie w omawianym trybie nie kończyła postępowania, lecz eliminowała jedynie zawisłość sprawy w sądzie ${ }^{86}$. Oznacza to, iż sprawa w takim przypadku wraca na etap postępowania przygotowawczego, którego gospodarzem jest prokurator ( $\mathrm{w}$ przeciwieństwie do zwrotu dokonanego na podstawie art. 396a k.p.k. - obecnie ponownie wprowadzonego, a poprzednio, przed 1 lipca 2015 r., uregulowanego w art. 397 k.p.k.) zobowiązany do uzupełnienia braków postępowania o czynności wskazane przez sąd. Dla konkretnej osoby, przeciwko której został wniesiony akt oskarżenia, ma to duże znaczenie, gdyż z chwilą uprawomocnienia się postanowienia o zwrocie sprawy prokuratorowi ta znowu wraca na etap postępowania przygotowawczego, a oskarżony staje się ponownie podejrzanym. W takiej sytuacji oskarżyciel publiczny, po uzupełnieniu postępowania przygotowawczego, może złożyć nowy akt oskarżenia, podtrzymać poprzedni albo złożyć wniosek o warunkowe umorzenie postępowania karnego lub sam umorzyć postępowanie przygotowawcze (art. 344b k.p.k.).

Kolejna sytuacja, kiedy określona osoba uzyskuje status oskarżonego, ma miejsce wtedy, gdy oskarżyciel publiczny występuje z wnioskiem do sądu o warunkowe umorzenie postępowania karnego. Wniosek o warunkowe umorzenie postępowania karnego jest rodzajem skargi inicjującej fazę sądową postępowania karnego, który należy traktować jako pismo zastępujące akt oskarżenia ${ }^{87}$. Jeżeli więc organ prowadzący postępowanie przygotowawcze uzna, że istnieją warunki do wystąpienia z takim wnioskiem, składa go zamiast aktu oskarżenia. A zatem z chwilą wniesienia do sądu wniosku o warunkowe umorzenie postępowania karnego podejrzany uzyskuje status osoby oskarżonej. Z kolei dla bytu oskarżonego jako strony procesowej nie ma większego znaczenia to, iż sąd może uznać, że takie warunkowe umorzenie byłoby nieuzasadnione, ponieważ wtedy wniosek taki zastępuje akt oskarżenia, a oskarżyciel publiczny uzupełnia go o czynności przewidziane w art. 333 § 1-2 k.p.k. Wobec tego dana osoba $\mathrm{w}$ dalszym ciągu pozostaje oskarżoną, a jedynie zmienia się

${ }^{86}$ R.A. StefaŃSKI. W: J. BratoszewsKi et al.: Kodeks postępowania karnego... T. II, s. 560; T. GrZegorczyK: Kodeks postępowania..., s. 769; P. Hofmański, E. SAdZIK, K. ZgryZeK: Kodeks postępowania karnego. T. II: Komentarz..., s. 336-337; L.K. PAPRZYCKI. W: J. GrajewsKi, L.K. PAprzycki, S. Steinborn: Komentarz aktualizowany do art. 1-424..., teza 1 do art. 345 k.p.k.

87 S. STACHOWIAK: Charakter prawny wniosku prokuratora o warunkowe umorzenie postępowania karnego przez sąd. Nowa kodyfikacja karna. Zagadnienia węzłowe. Kraków 1998, s. 177-178; K. ZgrYzeK: Skargi zastępujące..., s. 417; E. KRUK: Wniosek o warunkowe umorzenie postępowania. Zagadnienia wybrane. W: Teoretyczne i praktyczne problemy wspótczesnego prawa karnego. Ksiegga jubileuszowa dedykowana Profesorowi Tadeuszowi Bojarskiemu. Red. A. Michalska-Warias, I. Nowikowski, J. Piórkowska-Flieger. Lublin 2011, s. 868; M. Kurowski. W: B. Augustyniak et al.: Kodeks postępowania karnego... T. I, s. 1066. 
rodzaj wniesionej do sądu skargi. Należy ponadto dodać, że w przypadku wniosku o warunkowe umorzenie postępowania możliwy jest także zwrot sprawy w trybie art. 343a $§ 1$ k.p.k., ze względu na brzmienie art. 336 $\S 5$ k.p.k., który nakazuje odpowiednio stosować przepisy dotyczące aktu oskarżenia - z części poświęconej wstępnej kontroli aktu oskarżenia, a więc również art. $343 a$ k.p.k. ${ }^{88}$. Poza tym słusznie wskazywano wcześniej w orzecznictwie (na gruncie stanu prawnego do 1 lipca 2015 r.), że nie było ograniczenia spraw ze względu na rodzaj wniesionego do sądu dokumentu procesowego inicjującego fazę postępowania jurysdykcyjnego ${ }^{89}$. W związku z tym obecnie istnieje możliwość ponownego „przekształcenia się" oskarżonego w podejrzanego.

Zakres pojęcia oskarżonego należy uzupełnić, ponieważ jest nim także podejrzany - w tych wypadkach, gdzie ustawa ogólnie wskazuje na oskarżonego (art. 71 § 3 k.p.k.). Wprawdzie literalne brzmienie omawianej normy jest nieco inne, gdyż określa ona tylko to, że odpowiednie przepisy mają zastosowanie do osoby podejrzanego, tam gdzie ustawa używa ogólnego określenia oskarżony, lecz nie zmienia to wniosku przedstawionego wyżej. Regulacja taka oznacza, iż w tych sytuacjach, kiedy dany przepis dotyczy ogólnie oskarżonego, należy go zastosować nie tylko do oskarżonego określonego $\mathrm{w}$ art. 71 § 2 k.p.k., ale również do podejrzanego (z art. $71 \S 1$ k.p.k.). Wobec tego konkretny przepis będzie się odnosił do „oskarżonego w znaczeniu szerokim”, gdy norma może dotyczyć zarówno oskarżonego sensu stricte, jak i podejrzanego ${ }^{90}$. Przy czym w orzecznictwie pojawiło się słuszne stanowisko, że także na gruncie Kodeksu karnego należy posługiwać się pojęciem oskarżonego w znaczeniu ogólnym, gdyż ten akt prawny nie zawiera definicji oskarżonego ${ }^{91}$. Jednocześnie wskazuje się na odpowiednie stosowanie konkretnych przepisów, a więc

${ }^{88}$ Tak też na gruncie analogicznego stanu prawnego sprzed 1 lipca 2015 r.: R.A. StefańsKi. W: J. Bratoszewski et al.: Kodeks postępowania karnego... T. II, s. 561; P. Hofmański, E. SAdZIK, K. ZgrYZeK: Kodeks postępowania karnego. T. II: Komentarz..., s. 399; A. SAKowicz. W: K.T. BoratyŃsKa et al.: Kodeks postępowania karnego..., s. 755.

${ }_{89}$ Zob. m.in.: uchwała SN z dnia 25 października 2000 r., I KZP 24/00, OSNKW 2000, nr 11-12, poz. 96; wyrok SN z dnia 8 kwietnia 2002 r., V KKN 281/00, OSNKW 2002, nr 7-8, poz. 56; postanowienie SA w Katowicach z dnia 14 czerwca 2006 r., II AKz 379/06, LEX Omega nr 196104.

90 P. HofMańsKi, E. SADZIK, K. ZgryZeK: Kodeks postępowania karnego. T. I: Komentarz..., s. 484 .

${ }^{91}$ Wyrok SN z dnia 8 kwietnia 2002 r., V KKN 281/00 - zaaprobowany w doktrynie, zob. m.in.: Z. GostyŃski, S. ZAbŁocki. W: J. BratosZewsKi et al.: Kodeks postępowania karnego... T. I, s. 515; T. GrZEgorczYK: Kodeks postępowania..., s. 241; K.T. BoraTYŃsKA. W: K.T. BoratyŃsKa et al.: Kodeks postępowania karnego..., s. 201; W. GrZEszCZYK: Kodeks postępowania..., s. 122; S. Steinborn, J. Grajewski. W: J. Grajewski, L.K. Paprzycki, S. STEINBORN: Komentarz aktualizowany do art. 1-424..., teza 8 do art. 71 k.p.k. 
z uwzględnieniem sytuacji podejrzanego i etapu postępowania, w jakim on występuje. W doktrynie nazywa się taką osobę oskarżonym sensu largo, a więc w znaczeniu szerokim ${ }^{92}$.

Trzeba ponadto wskazać, że w doktrynie pojawiło się również pojęcie „oskarżonego w ujęciu najszerszym”, do zakresu którego zaliczono, oprócz oskarżonego i podejrzanego, także osobę podejrzaną ${ }^{93}$, a czasem nawet skazanego ${ }^{94}$.

Pojęcie oskarżonego w polskim Kodeksie postępowania karnego jest tak zdefiniowane, że moment „stawania się” oskarżonym jest ściśle określony i nierozerwalnie związany z fazą jurysdykcyjną procesu karnego. Natomiast ustawodawca wprost wskazał na sytuacje, kiedy daną osobę można określać oskarżonym, a moment uzyskania statusu oskarżonego nie jest sporny w doktrynie i orzecznictwie.

7.

Poza wyżej omówionymi pojęciami oskarżonego należy zastanowić się, jaki jest status procesowy osoby, wobec której skierowano w trybie art. 354 k.p.k. wniosek o umorzenie postępowania i zastosowanie środków zabezpieczających wobec sprawcy niepoczytalnego. Kodeks postępowania karnego raz bowiem określa taką osobę mianem podejrzanego (art. 354 k.p.k.), a raz osobą, której prokurator zarzuca popełnienie czynu zabronionego w stanie niepoczytalności (art. 380 k.p.k.). Tym samym osoba taka została nazwana w dwojaki sposób ${ }^{95}$, dlatego też należałoby postulować ujednolicenie terminologii w obrębie jednego aktu prawnego.

92 M. Cieślak: Postępowanie karne..., s. 32; W. Daszkiewicz: Prawo karne..., s. 249; Z. Sobolewski, P.K. Sowiński. W: G. ARTYMiak et al.: Proces karny. Część ogólna..., s. 119120; T. GrzegorczyK: Kodeks postępowania..., s. 242; E. Skrętowicz. W: R. КміeciK, E. Skrętowicz: Proces karny. Część ogólna..., s. 162; Z. Muras: Wyjaśnienia oskarżonego..., s. 50; P. HofMAŃsKi, E. SAdZIK, K. ZgryZeK: Kodeks postępowania karnego. T. I: Komentarz..., s. 484; T. BoratyŃsKa. W: K.T. BoratyŃsKa et al.: Kodeks postępowania karnego..., s. 200.

93 S. Waltoś: Proces karny..., s. 190; P. HofMański, E. SADZIK, K. ZgRYZeK: Kodeks postępowania karnego. T. I: Komentarz..., s. 484.

${ }^{94}$ F. Prusak: Komentarz do kodeksu postępowania karnego..., s. 274; K. Marszat. W: K. Marszae, S. Stachowiak, K. Zgryzek: Proces karny..., s. 189.

${ }_{95} \mathrm{Na}$ co zwrócono już uwagę w doktrynie: P. Niedzielak, K. Petryna. W: A. Kryże et al.: Kodeks postępowania karnego. Praktyczny komentarz z orzecznictwem. Warszawa 2002, s. 655-656; P. HofmaŃsKi, E. SADZIK. K. ZgryzeK: Kodeks postępowania karnego. T. II: Komentarz..., s. 499; A. WAŻNy. W: K.T. BoraTYŃsKA et al.: Kodeks postępowania karnego..., s. 802; S. ŁADoś: Pozycja prawna oskarżonego z zaburzeniami psychicznymi. Warszawa 2013, s. 301; chociaż w doktrynie uznaje się czasami te dwa pojęcia za równoznaczne - zob. W. KocIubIŃsKI: Orzekanie o środku zabezpieczającym z art. 94 § 1 nowego kodeksu karnego $w$ świetle nowego kodeksu postępowania karnego. PS 1999, nr 3, s. 128. 
Słusznie wskazywano w doktrynie na gruncie poprzedniego Kodeksu postępowania karnego z 1969 r., że osoba, w stosunku do której prokurator wystąpił z wnioskiem o umorzenie postępowania i zastosowanie środków zabezpieczających, nie była już podejrzanym, gdyż status ten utraciła z chwilą umorzenia postępowania przygotowawczego ${ }^{96}$ - warunku koniecznego do wystąpienia $\mathrm{z}$ omawianym wnioskiem. W obecnym stanie prawnym podmiot ten przestaje być podejrzanym dopiero $\mathrm{z}$ chwila złożenia wniosku do sądu ${ }^{97}$. Dlatego też osoba taka do tego momentu jest jeszcze podejrzanym i przysługują jej wszystkie uprawnienia tej strony procesowej, łącznie z możliwością zaznajomienia jej z materiałami postępowania przygotowawczego (art. $324 \$ 1 \mathrm{w}$ zw. z art. 321 k.p.k.). Jednakże należy zauważyć, że z chwilą złożenia wniosku do sądu staje się ona osobą, której prokurator zarzuca popełnienie czynu zabronionego w stanie niepoczytalności ${ }^{98}$. Trzeba przy tym zwrócić uwagę, że nie jest ona oskarżonym ${ }^{99}$, gdyż złożenie takiego wniosku nie jest „wniesieniem oskarżenia” czy też „złożeniem wniosku o warunkowe umorzenie postępowania" i nie mieści się w zakresie przepisu art. 71 § 2 k.p.k. ${ }^{100}$, a normy tej nie można rozumieć rozszerzająco ${ }^{101}$. Dlatego też trafniejsze byłoby nazywanie takiego uczestnika procesu „osobą, której wniosek dotyczy"102, by w ten sposób uniknąc karnistycznych konotacji tego pojęcia ${ }^{103}$. Słusznie także wskazuje się, że postępowanie przygotowawcze w stosunku do takiej osoby nie zostało jeszcze umorzone, a decyzja należy w tym przypadku do sądu i wobec tego używany termin „podejrzany”

${ }^{96}$ K. ZGryZeK: Postępowanie $w$ przedmiocie zastosowania środków zabezpieczajacych $w$ polskim prawie karnym. Katowice 1989, s. 143; podobnie w obecnym stanie prawnym: T. GrzegorczyK: Kodeks postępowania..., s. 808.

97 Odmiennie: I. NowIкOWsкI: Postępowanie $w$ przedmiocie wniosku o umorzenie postępowania i zastosowanie środków zabezpieczajacych (art. 324 k.p.k.) - zagadnienia wybrane. W: Skargowy model procesu karnego..., s. 279.

98 D. KARCZMARSKa: Glosa do uchwaty z 25 lutego 2005 r., I KZP 35/04. PS 2006, nr 1, s. 144 .

99 Odmiennie: W. Sych: Glosa do uchwaty SN z 25 lutego 2005 r., I KZP 35/04. PS 2006, nr 3, s. 136-137; IDEM: Wniosek prokuratora o umorzenie postępowania i zastosowanie środków zabezpieczajacych jako szczególny rodzaj skargi w polskim procesie karnym. W: Skargowy model procesu karnego..., s. 360.

100 Tak też: W. MarcinKowsKi: Glosa do uchwaty SN z 25 lutego 2005 r., sygn. akt I KZP 35/04. „Wojskowy Przegląd Prawniczy” 2005, nr 2, s. 140; T. GrzegorczyK: Kodeks postępowania..., s. 808; D. ŚwIECKI. W: B. AugustYNiaK et al.: Kodeks postępowania karnego... T. II, s. 135.

101 Odmiennie: M. Jeznach: Akt oskarżenia. Prok. i Pr. 2006, nr 11, s. 101-102.

102 K. ZgryzeK: Postępowanie $w$ przedmiocie zastosowania..., s. 145.

${ }^{103}$ K. ZGRYZeK: Pozycja procesowa podejrzanego $w$ postępowaniu $w$ sprawie zastosowania środków zabezpieczających. W: U progu nowych kodyfikacji karnych. Księga pamiątkowa ofiarowana profesorowi Leonowi Tyszkiewiczowi. Red. O. GóRnioK. Katowice 1999, s. 339-344. 
w stosunku do takiego podmiotu może być uzasadniony ${ }^{104}$. Tym samym wniosek o umorzenie postępowania i zastosowanie środków zabezpieczających jest skargą inicjującą postępowanie przed sądem pierwszej instancji w przedmiocie rozstrzygnięcia kwestii w nim wskazanej ${ }^{105}$. Jednakże nazywanie podejrzanym osoby, której dotyczy wniosek o umorzenie postępowania, nie da się pogodzić z etapem jurysdykcyjnym, w którym decyzja zostaje wydana. Dlatego też należałoby postulować zmianę przepisu art. $71 \S 2$ k.p.k. w ten sposób, by oskarżonym była również osoba, wobec której złożono wniosek o umorzenie postępowania i zastosowanie środków zabezpieczających ${ }^{106}$. W ten sposób można bowiem dostosować zakres pojęciowy oskarżonego do jurysdykcyjnego etapu postępowania karnego.

\section{8.}

Na zakończenie trzeba rozważyć czy „faktycznie podejrzanego” można traktować jak „podejrzanego” w rozumieniu kodeksowym. W praktyce bowiem zdarzają się nieliczne sytuacje, gdy organy procesowe, zamiast konkretnej osobie postawić zarzuty lub wydać wobec niej postanowienie o przedstawieniu zarzutów, przesłuchują ją w charakterze świadka, wbrew obowiązkowi wynikającemu z art. 313 § 1 lub 308 § 2 k.p.k. Z kolei przyznanie „faktycznie podejrzanemu” statusu strony procesowej pozwoliłoby m.in. na korzystanie przez niego z praw do obrony i odmowy składania wyjaśnień ${ }^{107}$. Jest rzeczą oczywistą, że w Kodeksie postępowania karnego nie przewidziano uprawnien dla „faktycznie podejrzanego”, ponieważ początkiem jego „bytu” w procesie karnym są niezgodne z przepisami działania organów ścigania. Poza tym sytuację procesową takiej osoby można rozważać dopiero po jej przesłuchaniu w charakterze świadka, wbrew obowiązkowi przesłuchania w charakterze podejrzanego. W dok-

${ }^{104}$ K. Zgryzek: Postępowanie $w$ przedmiocie zastosowania..., s. 144; poza tym w doktrynie wprost wskazuje się, iż po złożeniu wniosku mamy do czynienia z podejrzanym w postępowaniu sądowym - zob. J.K. GIERKowsKI, L.K. PAPRZYCKI: Niepoczytalność i psychiatryczne środki zabezpieczajace. Zagadnienia prawno-materialne, procesowe, psychiatryczne i psychologiczne. Warszawa 2013, s. 388.

105 K. ZgryzeK: Wniosek o zastosowanie środka zabezpieczajacego. „Problemy Prawa Karnego" 1989, nr 15, s. 51.

106 Tak też: K. ZgryzeK: Pozycja procesowa podejrzanego..., s. 340.

107 Szerzej na temat w kontekście konstytucyjnego prawa do obrony zob. P. NowaK: Definicja podejrzanego i oskarżonego a konstytucyjne prawo do obrony. CPKNP 2016, nr 4, s. 63 i nast. 
trynie $^{108}$ i orzecznictwie ${ }^{109}$, w stanie prawnym obowiązującym do dnia 14 kwietnia 2016 r., uznawano, że „faktycznie podejrzany” winien być podejrzanym w rozumieniu kodeksowym, ponieważ o wszczęciu postępowania $\mathrm{w}$ fazie in personam nie decydowało samo subiektywne podejście organu procesowego ${ }^{110}$. Natomiast wydanie postanowienia o przedstawieniu zarzutów miało charakter deklaratoryjny, potwierdzający istniejący stan dotyczący oceny zebranego materiału dowodowego ${ }^{111}$. Ponadto uznawano, iż prawo do obrony winno przysługiwać dopiero od momentu wszczęcia postępowania przygotowawczego, a zatem łączyć się z zagrożeniem procesowym, które przez jego wszczęcie staje się realne ${ }^{112}$. Dlatego też, jeżeli istniały przesłanki do wydania wobec określonej osoby postanowienia o przedstawieniu zarzutów (lub przedstawienia jej zarzutów), to należało już przyznać jej prawo do obrony ${ }^{113}$, a nie wolno było dopuszczać do przesłuchania w charakterze świadka ${ }^{114}$. Świadek posiadał bowiem tylko uprawnienie polegające na uchyleniu się od odpowiedzi na pewne pytania

108 P.K. SowiŃski: Prawo oskarżonego do milczenia oraz reguła nemo se ipsum accusare tenetur na tle dązenia organów procesowych do poznania prawdy materialnej $w$ procesie karnym. W: Zasada prawdy materialnej. Materiały z konferencji Krasiczyn 15-16 października 2005 r. Red. Z. Sobolewski, G. ARTYMiaK. Kraków 2006, s. 173; M. Filar: Glosa do uchwaty SN z 20 września 2007 r., I KZP 26/07. OSP 2008, nr 4, poz. 46, s. 304, 307-309; A. BŁachnio-Parzych, J. Kosonoga. W: A. BŁachnio-Parzych et al.: Rzetelny proces karny $w$ orzecznictwie sądów polskich i międzynarodowych. Red. P. WILIŃski. Warszawa 2009, LEX Omega, teza 582 w rozdziale VII - 3.7.2; D. GruszecKa: Zasięg prawa do obrony w kontekście odpowiedzialności za fatszywe zeznania. CPKNP 2010, nr 3, s. 146-147.

109 Wyrok SN z dnia 9 lutego 2004 r., V KK 194/03, OSNKW 2004, nr 4, poz. 42; wyrok TK z dnia 11 grudnia 2012 r., K 37/11, OTK-A 2012, nr 11, poz. 133; wyrok TK z dnia 3 czerwca 2014 r., K 19/11, OTK-A 2014, nr 6, poz. 60.

110 Podobnie: P.K. Sowiński: Prawo świadka do odmowy zeznań w procesie karnym. Warszawa 2004, s. 10-11; P. WILIŃsKI: Zasada prawa do obrony $w$ polskim procesie karnym. Kraków 2006, s. 560; Z. Muras: Wyjaśnienia oskarżonego..., s. 95; A. SAKowicz. W: K.T. BoratYŃsKa et al.: Kodeks postępowania karnego..., s. 35.

111 D. GruszecKa: Zasięg prawa..., s. 146-147.

112 A. BoJAŃCZYK: W kwestii zawiq̨zania się konstytucyjnej gwarancji prawa do obrony $w$ czasie - uwagi na marginesie wyroku TK z dnia 1 grudnia 2009 r. W: Funkcje procesu..., s. 368; podobnie: M. BIELsKI: Wyłaczenie przestępności składania fałszywych zeznań $w$ zwiazku z przystugujacym sprawcy czynu zabronionego prawem do obrony. CPKNP 2011, nr 3, s. 80-81.

113 Tak też: P.K. Sowiński: Prawo oskarżonego..., s. 173; J. Potulski: Glosa do uchwały SN z 26 kwietnia 2007 r., I KZP 4/07. GSP 2008, nr 3, poz. 11, s. 114-115; A. GABERLE: Dowody w sqdowym procesie karnym. Teoria i praktyka. Warszawa 2010, s. 136-137; M. BIELSKI: Wyłączenie przestępności składania fatszywych zeznań..., s. 82; G. JĘDRzEJEWsKI: Odpowiedzialność karna..., s. 75.

114 Wyrok SN z dnia 21 stycznia 1982 r.; wyrok SN z dnia 4 lipca 2000 r., WKN 12/00, LEX Omega nr 438511. 
(które byłoby niewystarczające ${ }^{115}$ ), a oskarżony mógł odmówić składania wyjaśnień. Oznacza to, że świadka można byłoby „zmusić” do złożenia zeznań ${ }^{116}$. Tym samym wskazywano, że „faktycznie podejrzanemu” trzeba było przyznać prawo do obrony, który przez niewłaściwe zachowanie organów ścigania stawał się właśnie podejrzanym ${ }^{117}$. Samo przyznanie prawa do obrony takiej osobie chroniło ją przed nadużyciami organów procesowych, które mogły świadomie zwlekać z postawieniem zarzutu, a nawet celowo przesłuchać kogoś w charakterze świadka. Wobec tego, przyznając „faktycznie podejrzanemu” prawo do obrony, można było zapobiec lub co najmniej ograniczyć dowolność w podejmowaniu decyzji o przedstawianiu zarzutów ${ }^{118}$. Nie byłoby z kolei wystarczające potraktowanie tak złożonych zeznań jako niewywołujących ujemnych skutków procesowych dla świadka, który winien być przesłuchany w charakterze podejrzanego (art. 16 k.p.k.). A to choćby dlatego, że takie zeznania mogłyby zostać np. później wykorzystane w postępowaniu karnym, mimo że składający je nie ponosiłby odpowiedzialności karnej za ich treść.

Po wprowadzeniu przepisu art. $233 \S 1$ a k.k., pozwalającego na karanie faktycznych sprawców przestępstwa za składanie fałszywych zeznań (zeznawanie nieprawdy lub zatajanie prawdy z obawy przed odpowiedzialnością karną grożącą składającemu zeznanie lub jego najbliższym), jeśli wcześniej przesłuchano ich w charakterze świadków, wyżej wymienione poglądy stają się właściwie nieaktualne. Ustawodawca bowiem zdecydował się na uregulowanie przewidujące karalność składania fałszywych zeznań przez osobę będącą sprawcą czynu zabronionego do chwili nabycia przez nią statusu podejrzanego. Jednakże wprowadzenie takiej regulacji należy ocenić krytycznie. Trzeba bowiem podkreślić, że przesłuchanie w charakterze świadka, wbrew obowiązkowi postawienia danej osoby w stan podejrzenia, może sprzyjać temu, że organy ścigania będą mogły uzyskiwać od niej np. informacje o innych źródłach dowodowych,

115 A. LACH: Glosa do uchwaty SN z dnia 20 września 2007 r., I KZP 26/07. LEX Omega; S. STYPUŁA: Glosa do uchwaty SN z dnia 20 września 2007 r., I KZP 26/07. MoP 2008, nr 15, s. 836; A. SAKowicz. W: K.T. BoratyŃsKa et al.: Kodeks postępowania karnego..., s. 34-35.

${ }^{116} \mathrm{Na}$ co już zwrócono uwagę w doktrynie: M. CIEśLAK: Przestuchanie osoby podejrzanej o udziat $w$ przestępstwie, która nie występuje $w$ charakterze oskarżonego. PiP 1964, nr 5-6, s. 865; A. TЕ̨CZA-PACioneK: Pojęcie osoby podejrzanej..., s. 61.

117 Odmiennie: R. KмIECIK: Glosa do uchwaty SN z 20 września 2007 r., I KZP 26/07. Prok. i Pr. 2007, nr 12, s. 163; A. WĄSEK: Glosa do uchwaty SN z 20 czerwca 1991 r., I KZP 12/91. „Wojskowy Przegląd Prawniczy” 1992, nr 3-4, s. 74-75; M. WarchoŁ: Glosa do uchwaty SN z 26 kwietnia 2007 r., I KZP 4/07. „Wojskowy Przegląd Prawniczy” 2007, nr 3, s. 111; J. Czabański, M. WarchoŁ: Prawo do milczenia czy prawo do kłamstwa. Prok. i Pr. 2007, nr 12, s. 49.

118 G. KrzYsztofiuk: Prawo do obrony osoby podejrzanej..., s. 178. 
podczas gdy w przypadku prawidłowego działania ta miałaby prawo do odmowy składania wyjaśnień. Tym samym przesłuchanie $\mathrm{w}$ charakterze świadka stawiałoby tę osobę w niekorzystnej sytuacji, gdy zmuszałoby się ją do składania zeznań (pod rygorem odpowiedzialności karnej) przeciwko sobie, co jest sprzeczne z zasadami demokratycznego państwa prawnego $^{119}$ oraz z prawem do nieobciążania własnej osoby ${ }^{120}$. Świadek w takiej sytuacji kłamałby, narażając siebie na odpowiedzialność karną, nie ujawniając okoliczności przestępstwa, co pogorszyłoby jego sytuację procesową ${ }^{121}$. Z kolei niewystarczające jest skorzystanie w tym przypadku z uprawnienia do uchylenia się od odpowiedzi na pytania (art. $183 \S 1$ k.p.k.) ${ }^{122}$. A zatem takie przeprowadzanie czynności procesowych prowadzi do wielu nadużyć i zachęca organy ścigania do przesłuchiwania potencjalnych podejrzanych w charakterze świadków, wbrew obowiązkowi postawienia ich $\mathrm{w}$ stan podejrzenia. W związku z tym trafnie wskazuje się, iż nabycie gwarancji procesowych - wynikających z materialnego aspektu prawa do obrony i zasady nemo se ipsum accusare tenetur, łączyć należy z samym faktem popełnienia czynu zabronionego przez jego sprawcę, a nie formalnym uzyskaniem określonego statusu w postępowaniu karnym $^{123}$.

W związku z powyższymi rozważaniami trzeba stwierdzić, że osoba „faktycznie podejrzana” (a więc ta, której winno się postawić zarzuty, ale organy ścigania, wbrew obowiązkowi, nie stawiają jej w stan podejrzenia), do chwili wejścia w życie z dniem 15 kwietnia 2016 r. przepisu art. 233 $\S 1 \mathrm{a}$ k.k., znajdowała się w analogicznej sytuacji jak podejrzany. Wobec tego sprawca przestępstwa mógł wybrać dowolną strategię obronną, a więc albo milczeć, albo aktywnie się bronić. Natomiast przepis art. 233 $\S 1$ a k.k. może zachęcać organy ścigania do przesłuchiwania osób podejrzanych najpierw w charakterze świadków, kiedy zaistnieją przesłanki do przedstawienia im zarzutów. W związku z tym negatywnie należy ocenić wprowadzenie art. $233 \S 1 \mathrm{a}$ k.k., który pozostaje w sprzeczności nie tylko z prawem do obrony, uregulowanym w Kodeksie postępowania

119 R.A. STEFAŃSKI: Glosa do uchwaty SN z 26 kwietnia 2007 r., I KZP 4/07. OSP 2008, nr 3, poz. 29, s. 191.

${ }_{120}$ R. Koper: Prawo do obrony osoby podejrzanej. Prok. i Pr. 2016, nr 2, s. 18-19.

121 Z. Martyniak: Wspótuczestnik czynu w roli świadka (zagadnienia wybrane). Pal. 1985, nr 9, s. 49; M. BŁó́sKi: Wyjaśnienia oskarżonego..., s. 278.

122 A. LACH: Glosa do uchwaty SN z dnia 20 września 2007 r...; S. STYPUŁA: Glosa do uchwaty SN z dnia 20 września 2007 r..., s. 836; A. SAKowicz. W: K.T. BoratYŃsKa et al.: Kodeks postępowania karnego..., s. 34-35.

${ }_{123}$ M. BIELSKI: Wytączenie przestępności składania fatszywych zeznań..., s. 80-81; podobnie: A. BŁachnio-Parzych, J. Kosonoga. W: BŁachnio-Parzych et al.: Rzetelny proces karny $w$ orzecznictwie..., teza 582 w rozdziale VII - 3.7.2.; P. NowaK: Definicja podejrzanego i oskarżonego..., s. 84-85. 
karnego i Konstytucji ${ }^{124}$, ale i z zasadą nemo se ipsum accusare tenetur. $\mathrm{W}$ ten sposób rzeczywistemu sprawcy przestępstwa, przesłuchiwanemu w charakterze świadka, niezasadnie postawiono jedynie wybór - zeznawać prawdę lub skorzystać z prawa do odmowy odpowiedzi na pytania (względnie, w nielicznych przypadkach, z prawa do odmowy składania zeznań). Słusznie bowiem wskazuje się, iż konstytucyjne prawo do obrony (wynikające $z$ art. 42 ust. 2 Konstytucji RP) winno przysługiwać nie tylko sprawcy czynu zabronionego, lecz także każdemu podmiotowi, wobec którego toczy się postępowanie karne (od momentu podjęcia wobec niego jakichkolwiek czynności), gdyż tylko w ten sposób nadaje mu się realny i efektywny kształt ${ }^{125}$. Podkreślenia wymaga, iż osoba przesłuchana w charakterze świadka, będąca rzeczywistym sprawcą przestępstwa, odmawiając odpowiedzi na pytania lub składania zeznań, wskazywałaby pośrednio, że jest właśnie jego sprawcą, tym samym oskarżając samą siebie. W ten sposób „dawałaby sygnał” organom ścigania, że wokół niej powinny koncertować działania, które z kolei miałyby już przypuszczenie co do sprawcy przestępstwa. Poza tym organy ścigania mogłyby też celowo przesłuchiwać osobę podejrzaną $\mathrm{w}$ charakterze świadka, kiedy posiadają już takie dowody, które uzasadniają przedstawienie jej zarzutów, np. licząc na to, że uzyskają jeszcze jakieś inne informacje na temat przestępstwa od świadka, niemającego prawa do odmowy składania wyjaśnień. Zwłaszcza że takie działanie organów ścigania nie jest wyraźnie penalizowane. A przecież każdemu, przeciw komu prowadzone jest postępowanie karne, przysługuje prawo do obrony, i to we wszystkich stadiach postępowania, bez skonkretyzowanego statusu takiej osoby ${ }^{126}$. Dlatego też nie można zgodzić się z poglądem, że przepis art. $233 \S 1 \mathrm{a}$ k.k. zabezpiecza wymiar sprawiedliwości przez wprowadzanie $\mathrm{w}$ błąd $\mathrm{w}$ wyniku składania fałszywych zeznań ${ }^{127}$. A to dlatego, że przepis ten stoi w ewidentnej sprzeczności z konstytucyjnym prawem do obrony. Należy bowiem wskazać, iż z punktu widzenia faktycznego sprawcy czynu zabronionego postępowanie karne prowadzone jest przeciwko niemu już z momentem podjęcia wobec niego jakiejkolwiek czynności zmierzającej do wyjaśnienia okoliczności popełnionego przestępstwa, a w konsekwen-

124 Tak też: J. ZaGrodniK: Metodyka pracy obrońcy i petnomocnika..., s. 111; W. HermelińsKi, B. Nita-ŚwiATŁowsKa: Kilka uwag o prawie do obrony $w$ zwiazku z nowelizacja Kodeksu postępowania karnego z 2016 roku. Pal. 2016, nr 9, s. 18-21; P. NowaK: Definicja podejrzanego i oskarżonego..., s. 84-85.

125 P. NowaK: Definicja podejrzanego i oskarżonego..., s. 72; podobnie: W. HeRMELIŃsKI, B. Nita-ŚwiatŁowsKa: Kilka uwag o prawie do obrony..., s. 19.

126 A. Sakowicz. W: System prawa karnego procesowego. T. VI: Strony..., s. 774; podobnie: P. NowaK: Definicja podejrzanego i oskarżonego..., s. 72.

127 I. Zgoliński. W: V. Konarska-Wrzosek et al.: Kodeks karny. Komentarz. Red. V. KonarsKa-WrzoseK. Warszawa 2016, s. 1041. 
cji jego wykrycia i ukarania ${ }^{128}$. Dlatego też taka osoba winna korzystać wcześniej niż z momentem postawienia ją w stan podejrzenia z możliwości odmowy składania depozycji dowodowych oraz winno się ją zwolnić z obowiązku mówienia prawdy.

W omówionej wyżej sytuacji nie pozwala się rzeczywistemu sprawcy przestępstwa na realizację prawa do obrony, które nie może przecież zostać uzależnione od formalnego przedstawienia zarzutów. Trzeba zwrócić uwagę, iż prawo do obrony w znaczeniu konstytucyjnym obejmuje całość toczącego się postępowania karnego, bez możliwości eliminacji z niego postępowania wpadkowego lub też przygotowawczego, o ile wkraczają w zakres konstytucyjnych wolności i praw ${ }^{129}$. Dlatego też korzystanie $\mathrm{z}$ prawa do obrony jedynie w sytuacji wydania przez organy postępowania przygotowawczego stosownej formalnej decyzji procesowej w rzeczywistości ogranicza zasadę nemo se ipsum accusare tenetur, której celem jest ochrona przed zmuszaniem do aktywnego udziału w postępowaniu karnym. Rzeczywistemu sprawcy przestępstwa należy bowiem zagwarantować możliwość wyboru właściwej według niego samego strategii obronnej, a on sam musi być zabezpieczony np. przed celowymi działaniami organów ścigania przesłuchujących go w charakterze świadka. I to zwłaszcza w sytuacji, gdy organy ścigania, mając wystarczającą podstawę do postawienia kogoś w stan podejrzenia, nie czynią tego, lecz przesłuchują go w charakterze świadka. Poza tym trafnie wskazano jeszcze na gruncie poprzedniego stanu prawnego, iż penalizacja składania fałszywych zeznań przez sprawcę przestępstwa, który tak czy inaczej może ponieść konsekwencje prawne jego popełnienia, jest w rzeczywistości wtórną formą pociągnięcia do odpowiedzialności karnej za konsekwencje pierwotnie popełnionego czynu zabronionego ${ }^{130}$. W związku z tym należy postulować zmianę art. 233 § 1a k.k. w taki sposób, aby wyłączyć bezprawność przestępstwa składania fałszywych zeznań, kiedy ktoś, poprzez składanie depozycji dowodowych, chronił siebie, korzystając w ten sposób z prawa do obrony. Tylko w takim przypadku każdy w czasie przesłuchania w charakterze świadka byłby chroniony przed koniecznością sugerowania, iż to on ma związek z przestępstwem, które jest przedmiotem postępowania karnego, w którym zeznaje. Ponadto trzeba zwrócić uwagę na to, iż $\mathrm{w}$ takiej sytuacji chodzi jedynie o nieprawdziwe wypowiedzi osoby składającej zeznania, a nie o ewentualnie inne zabiegi mające na celu ukrycie swojego sprawstwa. Dlatego też niecelowe jest karanie rzeczywistych sprawców przestępstw dodatkowo za składanie fałszywych zeznań, jeżeli

128 P. Nowak: Definicja podejrzanego i oskarżonego..., s. 68.

129 Wyrok TK z dnia 28 listopada 2007 r., K 39/07, OTK-A 2007, nr 10, poz. 129; wyrok TK z dnia 27 października 2015 r., K 5/14, OTK-A 2015, nr 9, poz. 150.

130 M. BIELSKI: Wyłączenie przestępności składania fałszywych zeznań..., s. 92. 
złożyły wcześniej zeznania, będąc właśnie przesłuchiwani w charakterze świadków. W ten sposób bowiem - poprzez mówienie - chroniły swoją osobę przed przyszłą odpowiedzialnością karną.

\section{Bibliografia}

\section{Literatura}

Artymiak G. et al.: Proces karny. Część szczególna. Red. G. Artymiak, M. Rogalski, Z. SobolewsKi. Warszawa-Kraków 2007.

Artymiak G. et al.: Proces karny. Część ogólna. Red. G. Artymiak, M. Rogalski, Z. SobolEwSKI. Warszawa-Kraków 2007.

AugustyniaK B. et al.: Kodeks postępowania karnego. Komentarz. T. I. Warszawa 2013.

AugustyniaK B. et. al.: Kodeks postępowania karnego. Komentarz. T. II. Warszawa 2013.

AugustyniaK B. et al.: Kodeks postępowania karnego. Komentarz do zmian. Red. D. ŚwIECKI. Warszawa 2016.

BAJ A.: Czy osoba podejrzana jest strona postępowania przygotowawczego?. Prok. i Pr. 2016, nr 10.

BIELSKI M.: Wyłączenie przestępności składania fatszywych zeznań $w$ związku $z$ przystugujacym sprawcy czynu zabronionego prawem do obrony. CPKNP 2011, nr 3.

BŁACHNIO-PARZYCH A. et al.: Rzetelny proces karny $w$ orzecznictwie sądów polskich i międzynarodowych. Red. P. WILIŃsKI. Warszawa 2009.

BŁońsKi M.: Wyjaśnienia oskarżonego w polskim procesie karnym. Łódź 2011.

BOJAŃCZYK A.: W kwestii zawiązania się konstytucyjnej gwarancji prawa do obrony $w$ czasie - uwagi na marginesie wyroku TK z dnia 1 grudnia 2009 r. W: Funkcje procesu karnego. Księga jubileuszowa Profesora Janusza Tylmana. Red. T. GRzEGorCZYK. Warszawa 2011.

BoratyŃSKa K.T., ChOJNIAK Ł., JasińsKi W.: Postępowanie karne. Warszawa 2015.

BoratyŃSKa K.T. et al.: Kodeks postępowania karnego. Komentarz. Warszawa 2012.

BratoszewsKi J. et al.: Kodeks postępowania karnego. Komentarz. T. I. Warszawa 2003.

BratoszewsKi J. et al.: Kodeks postępowania karnego. Komentarz. T. II. Warszawa 2004.

BrodzISz Z. et al.: Kodeks postępowania karnego. Komentarz. Red. J. SKorupKA. Warszawa 2015.

CHAŁUbeK K.: Podjęcie na nowo czy wznowienie postępowania przygotowawczego $w$ fazie in rem z powodu znikomej społecznej szkodliwości czynu „faktycznie podejrzanego”. „St. Prawno-Ekonomiczne” 2011, nr 84.

Cieślak M.: Postępowanie karne. Zarys instytucji. Warszawa 1982.

CIEŚLAK M.: Przestuchanie osoby podejrzanej o udziat w przestępstwie, która nie występuje $w$ charakterze oskarżonego. PiP 1964, nr 5-6. 
Czabański J., Warchoł M.: Prawo do milczenia czy prawo do kłamstwa. Prok. i Pr. 2007, nr 12.

Czapigo A.: Oskarżony jako źródło dowodowe. „Prokurator” 2001, nr 1.

CzAPIgo A.: Osoba podejrzana jako podmiot uprawniony do wniesienia zażalenia na postanowienie o umorzeniu postępowania przygotowawczego. „Wojskowy Przegląd Prawniczy" 2009, nr 2.

Czarnecki P.: Czy osobie podejrzanej przystuguje prawo do obrony? Przyczynek do krytycznej analizy zagadnienia $w$ kontekście obowiązu poddania tej osoby badaniu alkomatem. W: Prawo do obrony: teoria a rzeczywistość. Red. A. ŚWIATŁOWSKI. Kraków 2012.

Daszkiewicz W.: Prawo karne procesowe. Zagadnienia ogólne. T. I. PoznańBydgoszcz 1999.

DudKa K., Paluszkiewicz H.: Postępowanie karne. Warszawa 2016.

DzIDuszko B.: Postępowanie $w$ przedmiocie kontroli formalnej aktu oskarżenia na podstawie art. 337 \$ 1 k.p.k. „Studia Iuridica Lublinensia” 2011, nr 16.

DzIUGIEє I.: Sytuacja prawna osoby podejrzanej na tle przepisów kodeksu postępowania karnego z 1997 roku. Wybrane zagadnienia. W: Ochrona człowieka w świetle prawa Rzeczypospolitej Polskiej. Materiały z II Międzynarodowej Konferencji Naukowej. Miarki 18-19 października 2001 r. Red. S. PIKULSKI. Olsztyn 2002.

EichSTAEDT K.: Postępowania szczególne $w$ polskim procesie karnym. Warszawa 2010.

FILAR M.: Glosa do uchwaty SN z 20 września 2007 r., I KZP 26/07. OSP 2008, nr 4, poz. 46.

GABERLE A.: Dowody w sadowym procesie karnym. Teoria i praktyka. Warszawa 2010.

GerecKA-ŻoŁYŃSKa A.: Przedstawienie zarzutu podejrzanemu $w$ świetle dyrektywy rzetelnego procesu. W: Prawo wobec wyzwań wspótczesności. Red. P. WiLIŃski. Poznań 2004.

Gierkowski J.K., PAPrzycki L.K.: Niepoczytalność i psychiatryczne środki zabezpieczajace. Zagadnienia prawno-materialne, procesowe, psychiatryczne i psychologiczne. Warszawa 2013.

Golık C: Wydanie postanowienia o przedstawieniu zarzutów. Prok. i Pr. 2014, nr 9.

Grajewski J., PAPrzycki L.K., STEINBorn S.: Komentarz aktualizowany do art. 1-424 ustawy z dnia 6 czerwca 1997 r. Kodeks postępowania karnego. LEX Omega 2015.

GRUSZECKA D.: Zasięg prawa do obrony w kontekście odpowiedzialności za fatszywe zeznania. CPKNP 2010, nr 3.

GrzegorczyK T.: Instytucja przedstawienia zarzutów $w$ postępowaniu uproszczonym. ZNUŁ 1974, nr 106.

GrZEgorczyK T.: Kodeks postępowania karnego oraz ustawa o świadku koronnym. Komentarz. Warszawa 2008.

GrzegorczyK T.: Nowy model postępowania przyspieszonego w sprawach karnych. Prok. i Pr. 2010, nr 4. 
GrzegorczyK T.: Wniosek o rozpoznanie sprawy w postępowaniu przyspieszonym jako surogat aktu oskarżenia. W: Skargowy model procesu karnego. Ksiega ofiarowana prof. Stanisławowi Stachowiakowi . Red. A. GERECKA-ŻoŁYŃsKA. Poznań 2008.

Grzegorczyk T., Tylman J.: Polskie postępowanie karne. Warszawa 2009.

GrZeszczyK W.: Kodeks postępowania karnego. Komentarz. Aktualizacja A. Herzog. Warszawa 2014.

HANAUSEK T.: Niektóre aspekty pracy z podejrzanym $w$ świetle kryminalistyki i procesu karnego. ZN ASW 1976, nr 16.

HermelińsKi W., Nita-ŚWiatŁowsKa B.: Kilka uwag o prawie do obrony $w$ zwiqzzu z nowelizacja Kodeksu postępowania karnego z 2016 roku. Pal. 2016, nr 9.

HofmańsKi P., SADZIK E., ZgryzeK K.: Kodeks postępowania karnego. T. I: Komentarz do artykutów 1-296. Warszawa 2011.

HofMAŃsKi P., SADZIK E., ZgryZEK K.: Kodeks postępowania karnego. T. III: Komentarz do art. 468-682. Red. P. HofMAŃsKi. Warszawa 2012.

JASIŃSKA M.R.: Źródła informacji o popetnionym przestępstwie. Szczecin 2016.

Jeznach M.: Akt oskarżenia. Prok. i Pr. 2006, nr 11.

JĘDRZEJEWsKi G.: Odpowiedzialność karna świadka za niektóre przestępstwa przeciwko wymiarowi sprawiedliwości. Prok. i Pr. 2017, nr 2, s. 59.

Kaftal A.: O ponownym wszczęciu prawomocnie umorzonego postępowania przygotowawczego. „Służba MO” 1964, nr 2.

KARCZMARSKA D.: Glosa do uchwaty z 25 lutego 2005 r., I KZP 35/04. PS 2006, nr 1.

KARSKI E.: Podejrzany a osoba podejrzana i ich charakter wedtug kodeksu postępowania karnego. NP 1976, nr 5.

KASIURA J.: Moment wszczęcia postępowania przeciwko osobie. „Prokurator” 2011, nr 2.

KASIŃSKI J.: Nowe rozwiązania $w$ zakresie trybu przyspieszonego po nowelizacji Kodeksu postępowania karnego. Mon. Praw. 2010, nr 20.

KLejNowsKa M.: Oskarżony jako osobowe źródło informacji o przestępstwie. Kraków 2004.

KlejNowsKa M.: Osoba podejrzana w procesie karnym. „Prokurator” 2003, nr 2.

KŁAK C.P.: „Osoba podejrzana” oraz „potencjalnie podejrzana” $w$ polskim procesie karnym a zasada nemo se ipsum accusare tenetur. IN 2012, nr 4.

KMIECIK R.: Akt oskarżenia jako pisemna forma skargi oskarżyciela publicznego. Prok. i Pr. 2010, nr 1-2.

KMIECIK R.: Glosa do uchwały SN z 20 września 2007 r., I KZP 26/07. Prok. i Pr. 2007, nr 12.

Kmiecik R., Skrętowicz E.: Proces karny. Część ogólna. Warszawa 2009.

KocIUBIŃsKi W.: Orzekanie o środku zabezpieczającym z art. 94 \$ 1 nowego kodeksu karnego w świetle nowego kodeksu postępowania karnego. PS 1999, nr 3.

KonarsKa-WrzoseK V. et al.: Kodeks karny. Komentarz. Red. V. KonArSKA-WrzoseK. Warszawa 2016.

Koper R.: Prawo do obrony osoby podejrzanej. Prok. i Pr. 2016, nr 2. 
Kosonoga J.: Przedstawienie i modyfikacja zarzutów a rola obrońcy. W: Obrońca $i$ petnomocnik $w$ procesie karnym po 1 lipca 2015 r. Przewodnik po zmianach. Red. P. WiLIŃsKi. Warszawa 2015.

KruK E.: Glosa do wyroku Sądu Najwyższego z 5 marca 2014 r., IV KK 341/13. IN 2016, nr 1.

KRUK E.: Wniosek o warunkowe umorzenie postępowania. Zagadnienia wybrane. W: Teoretyczne i praktyczne problemy wspótczesnego prawa karnego. Ksiega jubileuszowa dedykowana Profesorowi Tadeuszowi Bojarskiemu. Red. A. Michalska-Warias, I. Nowikowski, J. Piórkowska-Flieger. Lublin 2011.

Krzysztofiuk G.: Prawo do obrony osoby podejrzanej oraz faktycznie podejrzanego - uwagi na tle uchwat Sadu Najwyższego z 26.4.2007 r. (I KZP 4/07) oraz z 20.9.2007 r. (I KZP 26/07). W: Problemy prawa polskiego i obcego w ujęciu historycznym, praktycznym i teoretycznym. Cześć druga. Red. B.T. BiEŃKowski, D. SZAFRAŃsKI. Warszawa 2009.

Kryże A. et al.: Kodeks postępowania karnego. Praktyczny komentarz z orzecznictwem. Warszawa 2002.

Kurleto E.: Osoba „podejrzewana” o dokonanie przestępstwa. Prob. Praw. 1981, nr 6.

LACH A.: Glosa do uchwaty SN z 20 września 2007 r., I KZP 26/07. LEX Omega.

LEWCZYK P.: Nabycie prawa do posiadania obrońcy a instytucja przedstawienia zarzutów. Pal. 2011, nr 3-4.

LUDWICZEK A.: Wszczęcie postępowania przeciwko osobie jako moment przerwania biegu terminu przedawnienia karalności. „Iustitia” 2012, nr 2.

ŁAdoś S.: Pozycja prawna oskarżonego z zaburzeniami psychicznymi. Warszawa 2013.

ŁyCZYweK R.: Prawo oskarżonego do znajomości zarzutów, materiatów $i$ akt sprawy $w$ świetle nowego kodeksu postępowania karnego. NP 1969, nr 7-8.

MarCINKOWsKi W.: Glosa do uchwaty SN z 25 lutego 2005 r., sygn. akt I KZP 35/04. „Wojskowy Przegląd Prawniczy” 2005, nr 2.

MarszaŁ K., StachowiaK S., ZgryzeK K.: Proces karny. Katowice 2003.

MarTyNiaK Z.: Wspótuczestnik czynu w roli świadka (zagadnienia wybrane). Pal. 1985, nr 9.

MŁYNARCZYK Z.: O kilku zagadnieniach karno-procesowych na tle praktyki. NP 1961, nr 4.

Muras Z.: Wyjaśnienia oskarżonego $w$ procesie karnym i prawie karnym materialnym. Komentarz. Warszawa 2010.

MurzYNowsKi A.: Faktycznie podejrzany w postępowaniu przygotowawczym. Pal. 1971, nr 10.

NowaK P.: Definicja podejrzanego i oskarżonego a konstytucyjne prawo do obrony. CPKNP 2016, nr 4.

Nowak T., Stachowiak S.: Prawo karne procesowe. Dynamika postępowania. Poznań-Bydgoszcz 1999.

Nowikowski I.: Postępowanie $w$ przedmiocie wniosku o umorzenie postępowania i zastosowanie środków zabezpieczajacych (art. 324 k.p.k.) - zagadnienia wybra- 
ne. W: Skargowy model procesu karnego. Ksiega ofiarowana prof. Stanisławowi Stachowiakowi. Red. A. GerecKA-ŻoŁYńsKa. Poznań 2008.

Nowy słownik języka polskiego. Red. E. Sobol. Warszawa 2003.

Oтєо一sкi K.: Kryminalistyczne ujęcie położenia prawnego podejrzanych $w$ postępowaniu przygotowawczym. Warszawa 1982.

OwCZARSKI S.: Osoba podejrzana i podejrzany $w$ dochodzeniu nie cierpiacym zwłoki $w$ świetle badań. „Wojskowy Przegląd Prawniczy” 1994, nr 1.

PENNER L.: O zmianie przepisów postępowania karnego. NP 1956, nr 2.

PotUlski J.: Glosa do uchwaty SN z 26 kwietnia 2007 r., I KZP 4/07. GSP 2008, nr 3, poz. 11.

PRUSAK F.: Elementy przedstawienia zarzutów w procesie karnym. „Służba MO” 1970, nr 1.

PRUSAK F.: Faktycznie podejrzany $w$ procesie karnym. Pal. 1971, nr 3.

PRusaK F.: Komentarz do kodeksu postępowania karnego. Warszawa 1999.

PRusaK F.: Pociagnięcie podejrzanego do odpowiedzialności $w$ procesie karnym. Warszawa 1973.

Słownik języka polskiego. T. III: R-Z. Red. M. SzYMCZAK. Warszawa 1992.

Słownik języka polskiego. T. 5: Nie-Ó. Red. W. Doroszewski. Warszawa 1963.

Słownik języka polskiego. T. 6: P-Prę. Red. W. DoroszewsKi. Warszawa 1964.

Słownik języka polskiego. T. 8: S-Ś. Red. W. Doroszewski. Warszawa 1966.

Słownik języka polskiego. T. 9: T-Wyf. Red. W. DoroszewsKI. Warszawa 1967.

Słownik współczesnego języka polskiego. Red. B. Dunaj. Warszawa 1996.

SовоLEwsкі Z.: Osoba podejrzana oraz potencjalnie podejrzana $w$ znowelizowanym (2003) kodeksie postępowania karnego a gwarancje konstytucyjne. W: Problemy znowelizowanej procedury karnej. Materiały z konferencji naukowej RzeszówCzarna 17-18 października 2003 r. Red. Z. Sobolewski, G. ArtyMiaK, C.P. KŁaK. Kraków 2004.

SowIŃski P.K.: Prawo oskarżonego do milczenia oraz reguła nemo se ipsum accusare tenetur na tle dążenia organów procesowych do poznania prawdy materialnej $w$ procesie karnym. W: Zasada prawdy materialnej. Materiaty z konferencji Krasiczyn 15-16 października 2005 r. Red. Z. SobolewsKi, G. ArtymiaK. Kraków 2006.

SowIński P.K.: Prawo świadka do odmowy zeznań $w$ procesie karnym. Warszawa 2004.

SowIŃsKi P.K.: Uprawnienia składające się na prawo oskarżonego do obrony. Uwagi na tle czynności oskarżonego oraz organów procesowych. Rzeszów 2012.

STACHOWIAK S.: Charakter prawny wniosku prokuratora o warunkowe umorzenie postępowania karnego przez sąd. Nowa kodyfikacja karna. Zagadnienia węzłowe. Kraków 1998.

STEINBORN S.: Status osoby podejrzanej w procesie karnym z perspektywy Konstytucji RP (Uwagi de lege lata $i$ de lege ferenda). W: Państwo prawa $i$ prawo karne. Księga jubileuszowa Profesora Andrzeja Zolla. T. II. Red. P. Kardas, T. SROKA, W. Wróbel. Warszawa 2012.

STEINBORN S., WĄSEK-WiAdEREK A.: Moment uzyskania statusu biernej strony postępowania karnego z perspektywy konstytucyjnej i międzynarodowej. W: Wokót 
gwarancji współczesnego procesu karnego. Księga jubileuszowa Profesora Piotra Kruszyńskiego. Red. M. Rogacka-Rzewnicka, H. Grajewska-KraczKowsKa, B.T. BIEŃKOWSKA. Warszawa 2015.

STEFAŃSKI R.A.: Formalna kontrola aktu oskarżenia $w$ nowym kodeksie postępowania karnego. Prok. i Pr. 1998, nr 9.

Stefański R.A.: Glosa do postanowienia SN z 16 stycznia 2009 r., IV KK 256/08. Prok. i Pr. 2009, nr 9.

STEFAŃSKI R.A.: Glosa do uchwały SN z 26 kwietnia 2007 r., I KZP 4/07. OSP 2008.

STEFAŃSKI R.A.: Prawo do obrony osoby podejrzanej. W: Z problematyki funkcji procesu karnego. Red. T. GrzegorczyK, J. IzydorczyK, R. Olszewski. Warszawa 2013.

Stefański R.A.: Skuteczność przedstawienia zarzutów. Prok. i Pr. 2013, nr 6.

STEFAŃSKI R.A.: Zatrzymanie osoby podejrzanej o popetnienie przestępstwa z użyciem przemocy na szkodę osoby wspólnie zamieszkującej. W: Funkcje procesu karnego. Ksiega jubileuszowa Profesora Janusza Tylmana. Red. T. GrzegorczyK. Warszawa 2011.

StypuŁa S.: Glosa do uchwały SN z 20 września 2007 r., I KZP 26/07. Mon. Pr. 2008, nr 15.

SYcH W.: Glosa do uchwaty SN z 25 lutego 2005 r., I KZP 35/04. PS 2006, nr 3.

SYcH W.: Wniosek prokuratora o umorzenie postępowania i zastosowanie środków zabezpieczających jako szczególny rodzaj skargi $w$ polskim procesie karnym. W: Skargowy model procesu karnego. Ksiega ofiarowana prof. Stanisławowi Stachowiakowi. Red. A. GerecKA-ŻoŁYńsKa. Poznań 2008.

System prawa karnego procesowego. T. VI: Strony $i$ inni uczestnicy postępowania karnego. Red. C. Kulesza. Warszawa 2016.

System prawa karnego procesowego. T. X: Postępowanie przygotowawcze. Red. R.A. STEFAŃSKI. Warszawa 2016.

Świda Z., Ponikowski R., Posnow W.: Postępowanie karne. Część ogólna. Red. Z. Świda. Warszawa 2008.

TARACHa A.: Glosa do postanowienia SN z 2 lipca 2003 r., II KK 268/02. „Wojskowy Przegląd Prawniczy" 2006, nr 1.

TARNOWSKA D.: Różnice między dochodzeniem a śledztwem $w$ polskim procesie karnym. Szczecin 2009.

TęCzA-Paciorek A.M.: Pojęcie osoby podejrzanej i jej uprawnienia. Prok. i Pr. 2011, nr 11.

Uniwersalny słownik języka polskiego. T. II: K-Ó. Red. S. DuBISZ. Warszawa 2006.

Waltoś S.: Model postępowania przygotowawczego na tle prawnoporównawczym. Warszawa 1968.

Waltoś S.: Proces karny. Zarys systemu. Warszawa 2008.

WARchoє M.: Glosa do uchwaty SN z 26 kwietnia 2007 r., I KZP 4/07. „Wojskowy Przegląd Prawniczy" 2007, nr 3.

WĄSEK A.: Glosa do uchwaty SN z 20 czerwca 1991 r., I KZP 12/91. „Wojskowy Przegląd Prawniczy" 1992, nr 3-4.

WiLIŃsKi P.: Zasada prawa do obrony $w$ polskim procesie karnym. Kraków 2006.

WITKOWsKa K.: Strony procesowe $i$ ich reprezentanci $w$ postępowaniu przygotowawczym. Prok. i Pr. 2012, nr 9. 
WoźNIEWsKi K.: Glosa do postanowienia SN z 24 kwietnia 2007 r., IV KK 31/07. GPO 2008, nr 1, poz. 10.

ZAGRODNIK J.: Metodyka pracy obrońcy i petnomocnika $w$ sprawach karnych i karnych skarbowych. Warszawa 2016.

ZgrYZeK K.: Postępowanie $w$ przedmiocie zastosowania środków zabezpieczających $w$ polskim prawie karnym. Katowice 1989.

ZGRYZeK K.: Pozycja procesowa podejrzanego $w$ postępowaniu $w$ sprawie zastosowania środków zabezpieczajacych. W: U progu nowych kodyfikacji karnych. Ksiega pamiatkowa ofiarowana profesorowi Leonowi Tyszkiewiczowi. Red. O. GóRNIOK. Katowice 1999.

ZGRYZEK K.: Skargi zastępujące akt oskarżenia $w$ polskim procesie karnym. W: Skargowy model procesu karnego. Ksiegga ofiarowana prof. Stanisławowi Stachowiakowi. Red. A. GereckA-ŻoŁYńsKa. Poznań 2008.

ZGRYZEK K.: Wniosek o zastosowanie środka zabezpieczajacego. „Probl. Prawa Karnego" 1989, nr 15.

\section{Orzecznictwo}

Wyrok TK z 28 listopada 2007 r., K 39/07, OTK-A 2007, nr 10, poz. 129.

Wyrok TK z 11 grudnia 2012 r., K 37/11, OTK-A 2012, nr 11, poz. 133.

Wyrok TK z 3 czerwca 2014 r. K 19/11, OTK-A 2014, nr 6, poz. 60.

Wyrok TK z 27 października 2015 r., K 5/14, OTK-A 2015, nr 9, poz. 150.

Uchwała SN z 25 października 2000 r., I KZP 24/00. OSNKW 2000, nr 11-12, poz. 96.

Uchwała SN z 29 czerwca 2007 r., SNO 38/07. LEX Omega nr 471799.

Wyrok SN z 6 lutego 1962 r., IV K 961/60. LEX Omega nr 135554.

Wyrok SN z 4 lipca 2000 r., WKN 12/00. LEX Omega nr 438511.

Wyrok SN z 8 kwietnia 2002 r., V KKN 281/00. OSNKW 2002, nr 7-8, poz. 56. Wyrok SN z 9 lutego 2004 r., V KK 194/03. OSNKW 2004, nr 4, poz. 42.

Wyrok SN z 7 listopada 2006 r., IV KK 150/06. LEX Omega nr 295347.

Wyrok SN z 5 marca 2014 r., IV KK 341/13. LEX Omega nr 1444341.

Postanowienie SN z 24 kwietnia 2007 r., IV KK 31/07. LEX Omega nr 262649. Postanowienie SN z 16 stycznia 2009 r., IV KK 256/08. LEX Omega nr 486201. Wyrok SA w Katowicach z 18 września 2015 r., II AKa 268/15. LEX Omega nr 1962872.

Wyrok SA we Wrocławiu z 3 marca 2016 r., II AKa 35/16. LEX Omega nr 2023602.

Postanowienie SA w Katowicach z 14 czerwca 2006 r., II AKz 379/06. LEX Omega nr 196104.

Postanowienie SA w Krakowie z 27 marca 2013 r., II AKz 96/13. LEX Omega nr 1315686. 